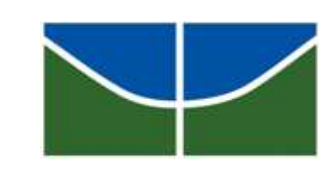

UNIVERSIDADE DE BRASÍLIA

Centro de Excelência em Turismo

Pós-graduação Lato Sensu

Curso de Especialização em Formação de Professores em Turismo

\title{
A ACESSIBILIDADE COMO FATOR DE \\ INCREMENTO DO TURISMO NA CIDADE DE FORMOSA - GO
}

\author{
Ana Beatriz de Azevedo Borges \\ Orientadora: Prof $f^{\mathrm{a}}$. Dr ${ }^{\mathrm{a}}$. Dulce Suassuna
}

Brasília - 2009 


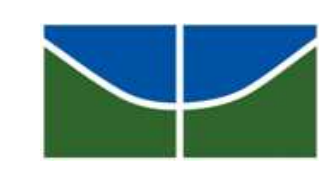

UNIVERSIDADE DE BRASÍLIA

Centro de Excelência em Turismo

Pós-graduação Lato Sensu

Curso de Especialização em Formação de Professores em Turismo

\title{
ACESSIBILIDADE E DESENVOLVIMENTO SUSTENTÁVEL: O TURISMO NA CIDADE DE FORMOSA - GO
}

\author{
Ana Beatriz de Azevedo Borges \\ Orientadora: Prof ${ }^{\mathrm{a}}$. Dr ${ }^{\mathrm{a}}$. Dulce Suassuna
}

Monografia apresentada ao Centro de Excelência em Turismo - CET, da Universidade de Brasília UnB, como requisito parcial à obtenção do grau de Especialista em Formação de Professores em Turismo.

Brasília - 2009 


\title{
UNIVERSIDADE DE BRASÍLIA
}

\section{Centro de Excelência em Turismo}

Pós-graduação Lato Sensu

\section{Curso de Especialização em Formação de Professores em Turismo}

Monografia apresentada ao Centro de Excelência em Turismo - CET, da Universidade de Brasília - UnB, como requisito parcial à obtenção do grau de Especialista em Formação de Professores em Turismo.

\section{ACESSIBILIDADE E DESENVOLVIMENTO SUSTENTÁVEL: O TURISMO NA CIDADE DE FORMOSA - GO}

\author{
Ana Beatriz de Azevedo Borges
}

Aprovado por:
Professora Dr ${ }^{\mathrm{a}}$. Dulce Suassuna
Orientadora

Professor Dr. Fernando Mascarenhas

Membro externo

Brasília, 22 de maio de 2009. 


\section{RESUMO}

O presente trabalho apresenta uma análise acerca das possibilidades do incremento do fenômeno turístico, tendo como aspecto norteador a acessibilidade. Para tanto, foi realizada uma pesquisa do tipo levantamento na Cidade Formosa - GO. Foi adotada como técnica de pesquisa a entrevista e os sujeitos investigados no estudo são moradores, comerciantes e gestores públicos locais. O quadro conceitual está definido por autores que analisam o turismo, seus aspectos sociais e econômicos e sua repercussão para o estabelecimento do desenvolvimento sustentável local. Tem-se como principal conceito o de acessibilidade, que é entendida, aqui, como uma forma de inclusão social das pessoas com deficiência ou mobilidade reduzida, seja ela permanente ou temporária, e, ainda, inclusão de idosos, crianças, grávidas, etc., ou seja, facilitando a utilização e o usufruto dos pontos turísticos por parte de toda a sociedade. Como resultado da pesquisa, aponta-se que: a acessibilidade pode ser uma estratégia adequada para o incremento do turismo em diferentes cenários, contudo tal estratégia ainda não se faz presente no contexto do município de Formosa/GO - o que pode suscitar como pressuposto que o turismo naquela cidade não apresenta contornos delimitados e não funciona como fator de desenvolvimento social em razão de não possibilitar a acessibilidade. Como forma de contribuir com o desenvolvimento social no contexto do município estudado, o trabalho traz uma lista dos pontos turísticos da cidade de Formosa, fazendo uma análise sobre a acessibilidade em cada um deles.

Palavras-chave: turismo, desenvolvimento sustentável, acessibilidade, pessoas com deficiente. Formosa/GO. 


\begin{abstract}
This essay analyzes the possibilities of increment of the tourist phenomenon, electing accessibility as one of its main factors. For that purpose, a research was carried through surveys in the city of Formosa-GO. Interview was adopted as research technique and the citizens surveyed in the study are inhabitants, businessmen and local public officers. The conceptual framework is defined by authors who analyze tourism, its social and economic aspects and its repercussion for the establishment of local sustainable development. It takes "accessibility" as its main concept, which is understood, here, as a means to social inclusion of persons with disabilities or reduced mobility, either permanent or temporary, and, still, to inclusion of elderly, children, pregnant women and others so that tourist points can be accessed and equally enjoyed by all people. As its result, the research concludes that accessibility can be a strategy used for the increment of tourism in different scenarios, notwithstanding the fact that that notion has not yet been fully applied in the city of Formosa-GO - what can lead to the conclusion that tourism in that city does not present delimited contours and does not yet function as a factor of social development due to a lack of accessibility. As a contribution to the social development in the context of the studied city, the essay brings a list of the tourist points of the city of Formosa, analyzing accessibility in each one of them.
\end{abstract}

Keywords: tourism, sustainable development, accessibility, people with disabilities, FormosaGO. 


\section{LISTA DE ILUSTRAÇÕES}

FIGURA 1: MECANISMO CONCEITUAL DE QUALIDADE 17

FIGURA 2: FESTA DO DIVINO ESPÍRITO SANTO 40

FIGURA 3: O SALTO DO ITIQUIRA 35

FIGURA 4: LAGOA FEIA 36

FIGURA 5: O BURACO DAS ARARAS 36

FIGURA 6: A GRUTA DAS ANDORINHAS 38

FIGURA 7: CATEDRAL DE NOSSA SENHORA DA IMACULADA CONCEIÇÃO 41

FIGURA 8: CASARÃO ANTIGO DA CIDADE DE FORMOSA 42 


\section{SUMÁRIO}

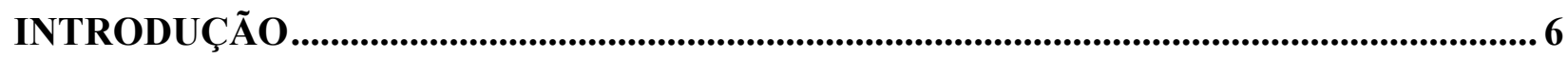

CAPÍTULO I - TURISMO, DESENVOLVIMENTO SUSTENTÁVEL E ACESSIBILIDADE: CONSTRUINDO O QUADRO CONCEITUAL ...................................... 8

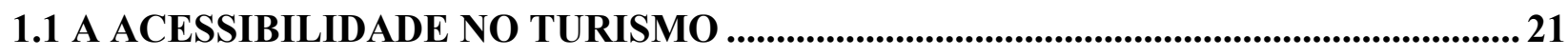

1.2 TURISTAS COM DEFICIÊNCIA............................................................................. 26

CAPÍTULO II - UM POUCO DA HISTÓRIA LOCAL - ALGUMAS NOTAS SOBRE O CAMPO

1.1 PESQUISA DE CAMPO............................................................................................... 31

CAPÍTULO III - FORMOSA: O TURISMO COMO ESTRATÉGIA PARA O DESENVOLVIMENTO SUSTENTÁVEL LOCAL E A ACESSIBILIDADE........................33

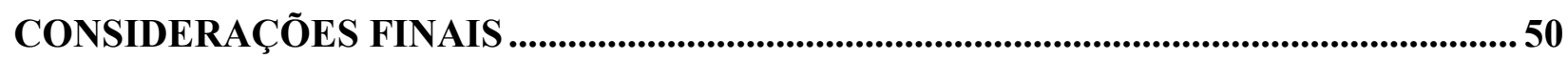

REFERÊNCIAS BIBLIOGRÁFICAS...................................................................................53

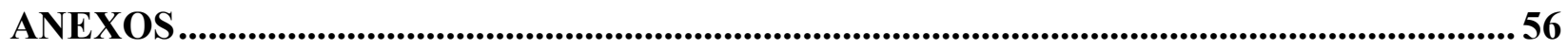




\section{INTRODUÇÃO}

Conforme os dados da OMT (2002) foram registrados 715 milhões de turistas estrangeiros no mundo todo, o que justifica o seu reconhecimento enquanto atividade econômica que mais cresce no mundo, passando a ser alvo de atenção por parte dos governos mundiais, como resultado de seu potencial gerador de emprego e renda e de benefícios econômicos, sociais, ambientais e, ainda, mecanismo para inclusão e transformação social.

Um dos novos aspectos para o desenvolvimento econômico e social do turismo é a acessibilidade. Nesse campo, ela pode ser entendida como a busca de oferta de condições adequadas para permitir a apropriação de cenários do turismo por parte de uma população constituída por pessoas com dificuldades de locomoção ou com outras necessidades especiais.

O objetivo geral desta pesquisa foi o de compreender o cenário do turismo na cidade de Formosa/GO, considerando como aspectos centrais a questão da acessibilidade e sua repercussão para o desenvolvimento sustentável local. Pretendeu-se, especificamente:

- Identificar as características relacionadas ao perfil do turista de Formosa/GO, visando compreender a necessidade do desenvolvimento de uma política para o desenvolvimento sustentável do turismo com base na acessibilidade.

- Identificar, com base nas visões dos moradores, comerciantes e gestores públicos, os espaços - pontos turísticos - e, as limitações destes em relação à acessibilidade, para o incremento do turismo como estratégia para o desenvolvimento sustentável local;

- Construir um roteiro turístico básico, indicando os pontos turísticos principais da cidade de Formosa/GO e analisando a(s) possibilidade(s) de acessibilidade.

Numa perspectiva de contribuição para o incremento do turismo local, apresenta-se, ao final, uma relação dos pontos turísticos da cidade de Formosa-GO, construindo-se, desta forma, uma 
análise preliminar sobre a possibilidade ou não de acessibilidade do turismo no contexto da cidade de Formosa/GO.

Espera-se, assim, colaborar com outros estudos sobre a acessibilidade como fator de incentivo ao turismo. O trabalho apresenta como limitações o fator temporal, o que impediu a realização de pesquisa em maior profundidade, tratando-se, portanto, de um estudo diagnóstico.

O presente trabalho está dividido em capítulos que tratam exclusivamente da relação do turismo com a acessibilidade. O capítulo 1 aborda a acessibilidade e o turismo, relatando as suas características e a importância deste fator para o incremento da atividade turística. O capítulo 2 conta a história de Formosa, seu surgimento e desenvolvimento. O capítulo 3 está fundamentado na importância do papel das políticas públicas locais para o incremento do turismo, na visão dos moradores e dos gestores municipais, identificando e analisando as características relacionadas ao perfil do turista de Formosa, visando compreender - a partir das visões dos moradores, bem como da dos gestores públicos - a necessidade da elaboração de uma política para o desenvolvimento do turismo contemplando também os aspectos relacionados à acessibilidade. $\mathrm{O}$ capítulo ainda enumerará os pontos turísticos de Formosa, elaborando uma relação destes locais que merecem ser visitados, atentado para o aspecto da existência ou não de meios adequados de acesso a todos os visitantes ou mesmo indicando a necessidade de criá-los.

Por fim, têm-se as considerações finais, onde são apresentados os resultados da pesquisa e lança-se mão de algumas proposições. 


\section{CAPÍTULO I - Turismo, desenvolvimento sustentável e acessibilidade: construindo o quadro conceitual.}

O turismo constitui um dos fenômenos sociais que pode engendrar possibilidades de assegurar o desenvolvimento sustentável, considerando, neste âmbito, particularmente, contextos específicos e que se reportam à viabilização do turismo rural ou mesmo de um modelo híbrido de turismo, que corporifique visitações ao meio urbano e ao rural. Para assegurar, notadamente, uma visão de turismo que culmine com o desenvolvimento sustentável é necessário "atender simultaneamente os critérios de relevância social, prudência ecológica e viabilidade econômica, os três pilares do desenvolvimento sustentável” (Sachs, 2000, p. 35).

Como se percebe da definição de Sachs (2000) a relevância social aparece como critério prioritário para a construção de uma proposta que contemple o desenvolvimento sustentável, neste âmbito, pode-se compreender que o papel do turismo - como fenômeno moderno e socialmente relevante à medida que assegura para a população local condições de sustentabilidade econômica - é central neste contexto.

Conforme Barreto (2006, p. 19) turismo é movimento de pessoas, é um fenômeno que

envolve, antes de mais nada, gente. É um ramo das ciências sociais e não das ciências econômicas e transcende a esfera das meras relações da balança comercial. Na mesma direção vão as considerações de Page (2001, p. 29), que além de tudo defende que "o estudo do turismo é um campo interdisciplinar".

Levando em consideração a ótica da ciência econômica, o turismo é conceituado como um serviço. Já para a ciência geográfica, em deslocamentos de pessoas de um ponto a outro sob a superfície terrestre. Sob a perspectiva sociológica, o conceito envolve a qualidade de vida da sociedade. Para as teorias humanas a atividade turística manifesta os valores da verdade, do amor, da criatividade, da liberdade do individuo, facilitando desta forma a comunicação entre os povos, potencializando a paz mundial. Portanto, cada disciplina define o seu conceito de turismo visando 
atender suas particularidades e necessidades específicas. Há, portanto, uma indefinição acerca do conceito de turismo, nesse sentido afirma a professora Deis Siqueira (2005, p.77):

(...) o turismo e a hospitalidade são os exemplos mais expressivos da confusão de reina sobre os conceitos (na verdade, ainda categorias ou conceitos com pequeno poder de generalização) que vem sendo utilizados. O próprio conceito de turismo está eivado de dubiedades, ambigüidades.

Essa ênfase dada na multidisciplinaridade gera controvérsia quanto à definição do turismo, em conseqüência da ótica das várias ciências ao qual o turismo está inserido. Segundo Córner (2001, p. 63), "há uma ausência de definições conceituais claras que delimitem a atividade turística e a distingam de outros setores".

A definição de turismo de Fuster, trazida por Margarita Barretto (2001, p. 11) mostra a transformação que ocorre em uma região quando nela se propõe trabalhar com a atividade turística:

Turismo é, de um lado, conjunto de turistas; do outro, os fenômenos e as relações que esta massa produz em conseqüência de suas viagens. Turismo é todo o equipamento receptivo de hotéis, agências de viagens, transportes, espetáculos, guias-intérpretes que o núcleo deve habilitar para atender às correntes (...). Turismo é o conjunto das organizações privadas e públicas que surgem para fomentar a infra-estrutura e a expansão do núcleo, as campanhas de propaganda (...). Também são os efeitos negativos ou positivos que se produzem nas populações receptoras.

O sistema econômico do turismo está inserido dentro do sistema econômico de uma região, de um país. É um sistema aberto, no qual os agentes econômicos estabelecem relações com outras localidades. Nesta perspectiva, o turismo é visto como gerador de riqueza, favorecendo a geração de empregos e é de grande importância para a criação do valor agregado bruto, na região receptora. Afinal, as entradas para o sistema turístico não são apenas no transporte e hospedagem, ele utiliza vários outros serviços como de alimentação, excursões, entretenimento. "Portanto, a 
atividade turística é geradora de fluxos de renda que permitem o aumento das entradas nos demais setores da atividade econômica, redistribuindo a renda num círculo cada vez maior" (OMT, 2001, p. 12). Estas considerações podem ser estabelecidas como correlato para a terceira implicação do conceito de desenvolvimento sustentável, qual seja, a viabilidade econômica da atividade a ser desenvolvida na região.

A Organização Mundial do Turismo (2001) definiu o turismo como atividades realizadas pelas pessoas durante suas viagens e estadas em lugares diferentes do seu entorno habitual, por um período consecutivo inferior a um ano, por lazer, negócio ou outros. Neste âmbito, o turismo é entendido como um fenômeno que compreende o deslocamento e estadia temporária, reunindo todo o conjunto de atividades disponíveis para possibilitar o deslocamento e a permanência provisória das pessoas e compreende pelo menos duas das características do desenvolvimento sustentável, a saber: relevância social e viabilidade econômica, apresentando, todavia, como um aspecto limitador da aplicação na íntegra do conceito de desenvolvimento sustentável ao turismo, o fato de esta atividade produzir, por vezes, impacto ambiental e não gerar nos empreendedores do turismo de modo geral o sentimento de responsabilidade ambiental.

De outro lado, uma característica importante do turismo é que todo o proveito decorrente dos serviços postos à disposição do turista serve da mesma forma para melhorar a qualidade de vida do cidadão local, à medida que gera emprego e renda nas comunidades que o exploram. Por isso, o turismo é visto como uma ferramenta de desenvolvimento.

Já o transporte diz respeito ao "movimento de passageiros, entre pares de localidades, em um período de tempo determinado" (Decreto $\mathrm{n}^{\circ} 2.521$ de 20 de março de 1998). Demanda turística diz-se do total de pessoas que viajam ou desejam viajar para usufruir os serviços turísticos em lugares diferentes daquele diferente da residência habitual.

O conceito de demanda está intimamente relacionado ao processo de tomada de decisões que as pessoas realizam constantemente no processo de planejamento de suas atividades de lazer e, portanto, sua escolha depende de numerosos fatores não só econômicos, como também psicológicos, sociológicos, fisiológicos e éticos. (CÓRNER, 2001, p.53) 
A viagem turística, no contexto atual, conforme Castelli (2001, p.192), é feita em grandes volumes e de diversas formas. Elas podem ser analisadas sob vários aspectos. Sendo eles:

- Quanto à motivação: Lazer; negócios; saúde etc.

- Quanto aos meios de transporte: aéreo; marítimo; fluvial; ferroviário e rodoviário.

- Quanto à sua duração: Curta e longa permanência.

- Quanto aos meios de hospedagem: hotéis; pousadas; camping.

- Quanto ao tamanho do grupo: individual; familiar; coletivo.

- Quanto ao preço: luxo, social.

Turistas, viajantes e visitantes formam a demanda turística e, por trás desse termo, encontra-se um grupo heterogêneo de pessoas. A diferença entre viajante e visitante segundo a Organização Mundial do Turismo é que viajante diz-se de qualquer pessoa que viaja entre dois ou mais países ou entre duas ou mais localidades em seu país de residência habitual e de visitante todos os tipos de viajantes relacionados ao turismo. O turista é aquele que executa um movimento de partir, permanecendo por determinado período - estadia - retornando a sua cidade de origem, portanto diz-se daquele que age turisticamente.

A diferença entre turista e excursionista é que o turista permanece uma noite, pelo menos, em um meio de alojamento coletivo ou privado do país visitado e o excursionista viajante não pernoita num meio de alojamento coletivo. $\mathrm{O}$ visitante internacional diz-se de toda pessoa que viaja por um período não superior a 12 meses, para um país diferente daquele que reside, fora de seu entorno habitual e cujo motivo principal não seja exercer uma atividade remunerada no país visitado.

O visitante interno designa toda pessoa que reside num país e que viaja, por um tempo não superior a 12 meses, para um lugar de seu país diferente do seu entorno habitual e cujo principal não seja o de exercer uma atividade remunerada no lugar visitado. 
Há, basicamente, duas categorias de turistas: os que usam os serviços especializados de turismo antes de iniciar sua viagem, transferindo aos profissionais da área a inteira responsabilidade pela intermediação e organização das atividades turísticas, e os que preferem realizar suas viagens de maneira independente, com espírito aventureiro, incluindo a demanda que opta pelo transporte regular.

Os turistas realizam viagens por vários motivos, que determinam os diversos segmentos do turismo, como no exemplo abaixo: (BARRETTO, 2006, p.17).

MOTIVAÇÕES DE VIAGENS

\section{SEGMENTOS DO TURISMO}

Turismo de negócios

Turismo de eventos

Turismo de entretenimento

Turismo de saúde

Turismo educacional

Turismo de aventuras

Turismo de gastronômico

Turismo cultural

Em função do lugar de origem dos turistas e do destino escolhido por eles o turismo pode ser classificado em:

- Turismo doméstico: residentes visitando seu próprio país.

- Turismo receptivo: não residentes procedentes de um determinado país.

- Turismo emissivo: residentes no próprio país que vão a outros países.

- Turismo interior: domestico e receptivo.

- Turismo nacional: doméstico e emissor.

- Turismo internacional: emissor e receptor. 
O turismo internacional caracteriza-se pelas viagens com a transposição de uma ou mais fronteiras internacionais, já o turismo nacional ou interno, é o que não ultrapassa os limites do próprio país de residência do turista.

O turista do século XXI mostra-se cada vez mais exigente, em função da tecnologia da informação e da globalização. Os avanços tecnológicos proporcionaram uma maior dinamicidade da informação então globalizada, sendo fatores contribuintes para a mudança do comportamento dos consumidores do turismo, que estão cada vez mais esclarecidos logo mais exigentes.

Page (2001, p. 298) observou que "os anos 90 destacam-se como a década do consumidor em relação às viagens turísticas, com empresas preocupadas e seguindo os padrões altos de conforto, confiabilidade e cortesia, como parte da experiência turística".

Os turistas consumidores ${ }^{1}$ estão cada vez mais exigentes e sofisticados, o que implica em verdadeiro desafio na gestão da qualidade dos serviços turísticos, que na atualidade requer a agregação de diferenciais, a ponto de despertar a paixão dos consumidores em função do ambiente competitivo das organizações na concomitante era da globalização, da informação e da tecnologia, portanto do consumidor, conforme Page (2001, p. 298):

A era do consumidor trouxe grandes desafios às empresas que englobam o sistema turístico, quando de gerir serviços de qualidade a fim de atender necessidades, a partir de altos padrões de conforto, confiabilidade e cortesia, enquanto parte da experiência de viagem.

Por isso segundo Page (2001, p. 298) “os passageiros estão sendo reconhecidos como clientes, e seus direitos e necessidades vão começando a ganhar um perfil mais importante na prestação, na qualidade e no gerenciamento dos serviços de transporte". Assim, afirma Córner (2001, p. 151):

\footnotetext{
${ }^{1}$ Consumidor: de acordo com Art. $1^{\circ}$ do Código de Defesa do Consumidor é aquele que adquire ou utiliza bem ou serviço como destinatário final.
} 
Assim como o incremento do turismo tem sido propiciado, em grande parte, pelo desenvolvimento dos meios de transporte, em sentido inverso, a crescente demanda turística, por sua vez, tem propiciado o desenvolvimento dos serviços e dos transportes e a melhora na qualidade dos mesmos. Efetivamente, os meios de transporte tiveram de se adaptar a uma demanda cada vez mais exigente e sofisticada, que busca bons preços e qualidade em seus deslocamentos, não só até o destino escolhido, como também dentro do mesmo.

Não há vida saudável e digna sem relações de consumo justas, satisfatórias e harmoniosas, formuladas com um ideal de boa-fé e justiça então, aplicável também às pessoas com deficiência, uma vez que o turismo é essencial para a atividade humana na atualidade. Logo, a qualidade deve ser alvo de atenção dos protagonistas responsáveis pela atividade turística como um todo, do deslocamento, a hospedagem e aos pontos turísticos. O turismo deve ser visto como mais do que um produto. Deve ser entendido também como um meio de inclusão social, como forma de respeito à alteridade, mesmo que de forma indireta. Nesse sentido, Deis Siqueira (2005, p. 163):

(...) o turismo e a hospitalidade são dominantemente oferecidos por escolas particulares, ou seja, educação como mercadoria. Mas este se torna particularmente instigante porque o profissional estará mais qualificado quanto mais aberto estiver para o novo paradigma, que não é apenas uma exigência da ciência, mas de toda a sociedade e também do mercado. O melhor Profissional, mesmo que esta competência seja lida, unilateralmente, como bom produtor e comerciante de mercadorias (o produto turismo), será, sem dúvida, o melhor formado (o que é muito mais do que informado), a partir das necessidades do novo estilo de vida, do novo paradigma e de uma nova visão de mundo em construção.

Juridicamente, a ação dos poderes públicos, em matéria de turismo, justifica-se a partir do momento em que se tem como pressuposto o direito de locomoção ligada à liberdade da pessoa humana. A tarefa do legislador é complexa tendo em vista a dinamicidade da atividade turística. Nesse sentido, afirma Aceranza (2002, p. 302 e 303): 
A normatização dos serviços turísticos é função importante do organismo nacional de turismo; essa tarefa inclui: a regulamentação de todas as instalações, facilidades e serviços desenvolvidos com fins turísticos; seu certificado, ou seja, a declaração da qualidade turística dos mesmos; a autorização dos preços e das tarifas sobre os serviços, certificados de qualidade turística dos mesmos; a autorização dos preços e das tarifas sobre os serviços, certificados de qualidade turística, em alguns casos, aplicáveis aos meios de hospedagem, as agências de viagens, aos operadores turísticos e do setor de transporte exclusivamente turístico.

Segundo Page (2001, p. 80) o papel do governo consiste em "promover e proteger os interesses dos consumidores contra práticas empresariais injustas e garantir que sejam mantidos os padrões de segurança...”. Assim, leciona Aceranza (2002, p. 303):

Considerando o viajante em sua condição de usuário das facilidades e dos serviços desenvolvidos para fins turísticos, o organismo de turismo deve se encarregar de estabelecer, em primeiro lugar as condições gerais as quais os contratos de prestação de serviços devem ser ajustados e, em segundo, os elementos relacionados à assistência do turista no conflito que, eventualmente, possa surgi entre as partes contratantes.

A intervenção do poder público em matéria de turismo também se dá por motivos econômicos, que segundo Córner (2001, p. 151) "se justifica pela existência de falhas no mercado, que explicam alguns dos problemas mais importantes que enfrenta”.

Nota-se o grau de importância do poder público no sentido de intervir para a promoção da qualidade na atividade turística, que se dá por meio de instrumentos legais, conjunto de leis, decretos, resoluções, financiamentos especiais e incentivos fiscais, empresas estatais, organismos oficiais de turismo - a fim de ordenar à atividade. 
A política turística neste trabalho é compreendida como toda a intervenção do poder público que leva a melhoria da atividade turística. Uma vez que segundo Acereza (2002, p. 62) “a política de turismo por ser uma política setorial, somente pode ser bem-sucedida se articulada com outras políticas setoriais e se entendida como uma pequena parte de um imenso jogo de relações”.

Os serviços estão sempre presentes em todo o processo produtivo das empresas que compõem o sistema de turismo no qual a visão para o aspecto da acessibilidade passa a ser uma parte integrante; neste sentido os serviços compõem um elemento diferenciador, então a qualidade é imprescindível para competitividade.

Há uma diferença entre comprar produtos e comprar serviços. Quem compra produtos costuma ter a visualização do que está comprando, pode tocar o produto, experimentá-lo ou testá-lo. Quando se adquire um serviço, na maioria das vezes, é impossível tocá-lo, experimentá-lo ou visualizá-lo antecipadamente. Uma vez que o serviço é imaterial, é apenas o seu resultado final. Para Mamede (2004, p. 34):

Produto é um conceito que abrange tanto o serviço, quanto o bem, seja ele natural ou imaterial, seja ele de um processo de produção industrial, seja ele simplesmente um lugar [...] produto é tanto um bem quanto um serviço.

No turismo, os elementos de qualidade avaliados pelos turistas são: a imagem que o cliente tem em relação ao serviço; a imagem do pessoal com qual o cliente interage; a distinção do serviço em relação ao oferecido pela concorrência; o ambiente físico; o clima de trabalho no qual o serviço é formulado, projetado e prestado.

A percepção do cliente em relação à qualidade será cada vez melhor à medida que os benefícios da qualidade oferecida forem maiores do que as expectativas da qualidade esperada. A expectativa diz-se da "esperança de que algo, agradável ou desagradável, venha acontecer. 
Esperança fundada em supostos direitos, probabilidade ou promessas”, conforme Ximenes (2001). Esse processo pode ser mais bem visualizado com a figura abaixo:

Figura 1: Mecanismo conceitual de qualidade
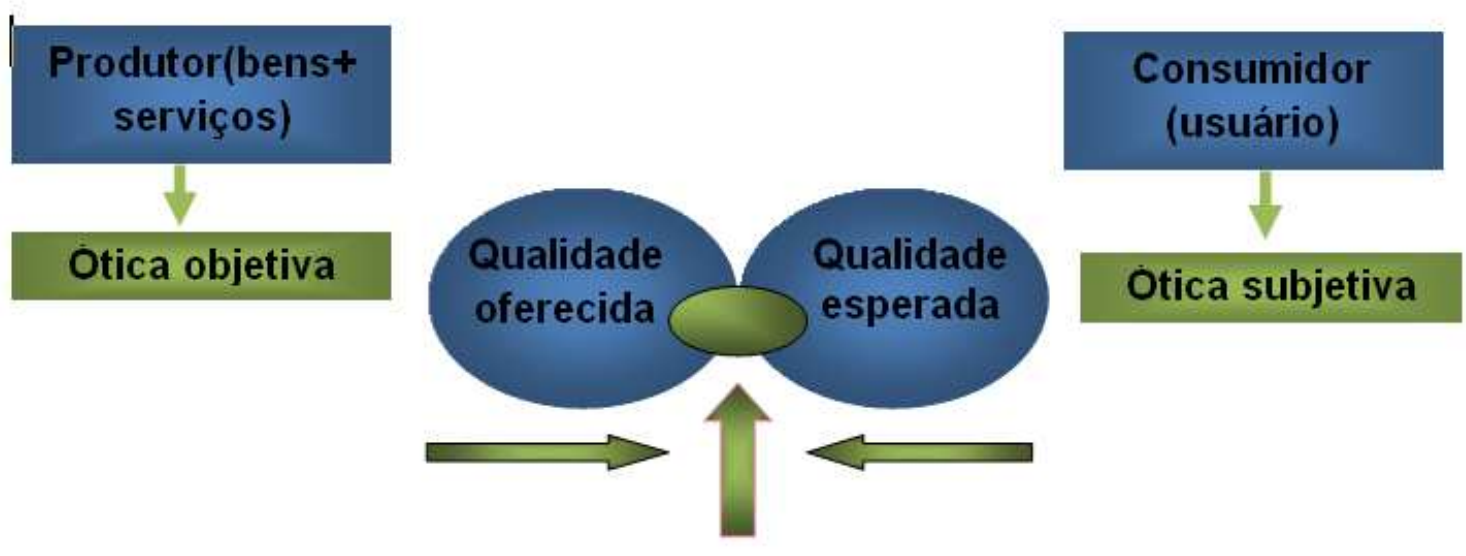

\section{Qualidade percebida}

Fonte: Castelli, Geraldo. s/l, s/d.

Como visto, a qualidade percebida diz-se da satisfação do cliente quando do atendimento e adequação das suas necessidades e expectativas geradas. Neste sentido um serviço de acessibilidade para o turismo de qualidade é aquele que atende as expectativas explícitas e implícitas dos indivíduos, de maneira particularizada, mas que ao mesmo tempo segundo Page (2001, p. 63), "procura atender a necessidades variadas e é parte integrante do conceito de prestação de serviço responsiva”. Córner (2001, p. 63) afirma que:

[...] não existem dois indivíduos iguais e suas decisões dependerão de suas atitudes (reflexo de valorização positiva ou negativamente alguma coisa), de suas 
percepções (impressões mentais do entorno), de suas personalidades (combinação de características psicológicas, que incluem gostos, preferências, etc.) e de suas experiências configuram juízos subjetivos dos consumidores, que influem no processo de decisão.

Pode-se afirmar que os elementos de qualidade do turismo junto com a acessibilidade apresentam várias vantagens de qualidade, que tornam o produto turístico mais atrativo, tais como: largas avenidas, rampas de acesso, iluminações adequadas, pessoas mais qualificadas para os cargos, atendimentos personalizados, etc.

Neste contexto o turista experimenta a viagem avaliando os elementos que compõem o serviço, então, a qualidade da experiência de viagem depende da qualidade da sua experiência com o serviço, que se torna um importante aspecto do que comporá toda a sua experiência de viagem turística. Castelli (2001, p. 143), diz que:

É o consumidor quem define e julga o que é qualidade. Ele o faz a partir da sua ótica, da ótica subjetiva. A qualidade dos bens é expressa pelos fornecedores, produtores, através da ótica objetiva, representada por inúmeras características que podem ser traduzidas em benefícios ou não para os clientes.

Neste sentido, a imagem do turista quanto à viagem se forma desde o embarque ao meio de transporte escolhido, logo, a experiência de viagem ocorre antes do embarque, no planejamento da viagem, a bordo do meio de transporte utilizado e finalmente no próprio destino turístico. Portanto, a acessibilidade é parte significativa na realização do sonho de viagem, que pode se tornar um pesadelo diante de um serviço inexistente ou prestado de forma inadequada.

Evidentemente, os profissionais que trabalham objetivando realizar sonhos devem se atentar para a importância da qualidade na acessibilidade não menosprezando a satisfação do usuário turista, já que o turismo para o viajante representa um serviço que serve para melhorar sua saúde física e mental, como afirma Lemos (2001, p. 21): 
O valor turístico está nos elementos sociais que, produzidos por uma coletividade em sua história e em sua relação com o meio ambiente, geram força de atratividade, provocando o deslocamento e a permanência de outros segmentos sociais espacialmente distantes que o validam. Lemos.

A atividade turística atua em dois sentidos: se por um lado depende dos atrativos naturais locais e das comodidades disponíveis proporcionadas por uma infra-estrutura adequada, por outro, também acaba pressionando sempre por melhores condições, como as sanitárias, de comunicação, de iluminação e as relacionadas à saúde e à acessibilidade.

O turismo influencia fortemente na conservação da cultura da região, mantendo vivas as tradições, os costumes e os patrimônios históricos. Esses são trabalhados e conservados, para que possam ser incluídos nas atividades turísticas. Impactos sociais positivos ocorrem com o crescimento turístico da região, tais como o intercâmbio cultural e o aumento da compreensão e o respeito às diferenças. Algumas das entidades responsáveis pelo turismo, pelo desenvolvimento e pela sua conservação são: a Organização Mundial do Turismo - OMT, o Governo Federal, os Governos estaduais e municipais, as empresas de regulamentação turística como a EMBRATUR, entre outras. São elas as responsáveis pelos investimentos e definição e execução de normas e procedimentos que serão desenvolvidos em todo o país e que possuem o poder de interferir mediante esses procedimentos, positivamente ou não, no crescimento desta atividade.

Quando vendemos um pacote turístico, principalmente no Brasil, estamos vendendo belezas naturais, atrativos naturais de um país tropical. Se oferecermos belezas, e não tivermos capacidade de atender a todas as pessoas sem discriminação estaremos dividindo os direitos e compartimentando os atrativos turísticos para pessoas com deficiência e sem deficiência.

As empresas estão, cada vez mais, adotando um modelo de negócios sustentáveis e acessíveis que contribuam para a conservação do meio ambiente, o desenvolvimento de uma sociedade mais justa - inclusão social - e o bom andamento do próprio empreendimento econômico. 
O investimento das empresas em negócios acessíveis está cada vez maior, em busca das oportunidades de um mercado de inovação, de uma realização ideológica, da conquista de novos clientes e de um modo mais moderno de fazer dinheiro.

Ao trabalhamos no turismo com acessibilidade, analisamos com cuidado a comunidade local. Essa política de turismo protege tanto a comunidade quanto as suas diferenças. A idéia é que haja a participação da comunidade e dos seus diversos segmentos no planejamento turístico e no controle das atividades da indústria do turismo nas localidades, para que ocorra o crescimento com inclusão de toda a sociedade.

Há, entre os estudiosos do turismo, dificuldades em alcançarem um consenso sobre a idéia de comunidade. Swarbrooke (2001, p. 63) diz que "A idéia de comunidade é uma idéia aconchegante, confortável, na qual pessoas que vivem numa área compartilham um senso de propósito e identidade. Ela sugere estabilidade e consenso, um conceito atraente num mundo em que talvez a mudança e o conflito sejam muito mais comuns".

O “consenso" se alcança, quase sempre, artificialmente pela imposição de uma parcela dominante da população sobre as demais. Na maioria das comunidades, observamos que existem conflitos, o que torna difícil o desenvolvimento de qualquer atividade em conjunto. Essas dificuldades podem ser geradas pelo turismo, mas também podem ser problemas que datam de outras questões e épocas. Por isso, as autoridades que elaboram os planejamentos turísticos precisam conquistar a simpatia da população e fazer com que o máximo de pessoas da localidade se envolva e participe efetivamente na atividade turística, explicando e buscando a sua colaboração na definição dos pontos positivos e negativos de todas as resoluções em questão.

A importância do envolvimento da comunidade é exatamente garantir a participação democrática da população local, ouvir e ponderar com os que são mais afetados pelo turismo, assegurar que as decisões tomadas estejam bem fundamentadas, reduzir os conflitos potenciais entre os turistas e a comunidade local, reduzir os impactos negativos do turismo - o desenvolvimento incorreto, o mal cuidado com os atrativos turísticos, a falta de preservação e de restauração, no caso, a dificuldade de acesso nos pontos turísticos, entre outros. 
Envolver as pessoas em uma atividade comum como trabalhar com o turismo, especialmente com o turismo sustentável e acessível, é uma tarefa difícil e demorada, pois precisamos reeducar várias pessoas em novos conceitos, ensinando-as a preservar, cuidar, manter, limpar, respeitar e garantir a inclusão social tanto daqueles que vivem do como usufruem do turismo. No Brasil, já podemos verificar vários projetos no turismo para pessoas com deficiência, como por exemplo, o Guia São Paulo Adaptada, (http://www.brasilparatodos.com.br/), lançado em 2001. Trata-se do primeiro guia de turismo a incluir e avaliar a acessibilidade das atrações, hotéis e restaurantes de 10 capitais brasileiras. As avaliações foram feitas por pessoas com deficiência em cada uma das capitais. Ele inclui indicações de hotéis que oferecem unidades adaptadas, informações sobre as condições de acessibilidade de restaurantes, bares e roteiro de compras, orientação para aprimorar o atendimento ao turista com deficiência e orientação de como promover a acessibilidade de estabelecimentos comerciais. Tudo isso, de maneira construtiva, seja valorizando as ações implementadas, seja também apontando as insuficiências.

\subsection{A acessibilidade no turismo}

A acessibilidade não é apenas o acesso ao meio edificado, à comunicação e à informação. Não é apenas a construção de rampas para cadeirantes. A acessibilidade significa criar um investimento no meio físico para todos, independentemente da situação física, psicológica ou sensorial de cada um. Neste grupo de pessoas incluem-se todas as pessoas com as mais diversas formas de incapacidade ou mobilidade reduzida, permanentes ou temporárias, idosos, grávidas, famílias com crianças, obesos, pessoas que transportam bagagem e pesos, etc.

A convenção sobre os Direitos das Pessoas com Deficiência (RESENDE, 2008, p. 66)

estabelece que todos os países devem adotar medidas para proteger as pessoas com deficiência contra todas as formas de violência, abuso e exploração. No Brasil, há uma grande quantidade de 
normas legais protegendo direitos de pessoas com deficiência, embora muitos casos não sejam eficazes nessa garantia(...).

Importante observar, de início, que para que se obtenha uma sociedade inclusiva é preciso que se passe pela análise do vocabulário a ser empregado para designar as pessoas que possuam qualquer tipo de deficiência, já que através da linguagem expressa-se preconceitos e discriminações. Nesse sentido afirma Sassaki (2003, p. 12-13):

(...) O conceito de deficiência se confunde com a história do próprio homem. Não da forma como passamos a enxergar os diversos tipos de deficiências, a partir da segunda metade do século XX, onde a tutela estatal sobre o tema começou a existir, mas com a conotação de menos valia, já descrita na Bíblia, onde termos como aleijado, surdo, cego, leproso aparecem de forma a denominar pessoas que necessitavam da piedade de outrem ou que precisavam "ser curados".(...)

(...) Por anos a fio esse foi o conceito de deficiência, algo a ser eliminado, a ser combatido, a ser excluído. (...)

Diversas nomenclaturas já foram empregadas para designar as pessoas com deficiências, desde a expressão "inválidas" (sem valor, em caráter claramente pejorativo), passando por “incapazes”, “deficientes”, “defeituosos”, “excepcionais”, “pessoas portadoras de deficiência” entre outros termos empregados. Até que, na década de 90, a nomenclatura "pessoas com deficiência", passou a ser a preferida, inclusive pelas próprias pessoas com deficiência.

Para Sassaki (2005), atualmente tende-se a deixar de usar a expressão "pessoa portadora de deficiência", uma vez que essas pessoas não "portam" sua deficiência, a deficiência é uma condição que faz parte das vidas dessas pessoas. Desse modo, Sassaki (2005) afirma que já é consensual o emprego da expressão "pessoas com deficiência" em manifestações orais e escritas no mundo todo, sendo essa, inclusive, a denominação utilizada pela Convenção sobre os Direitos das Pessoas com Deficiência, da Assembléia Geral das Nações Unidas, aprovada em 06 de dezembro de 2006. 
Acessibilidade é justamente um processo de transformação do ambiente e de mudança da organização das atividades humanas visando à diminuição dos efeitos do meio sobre a deficiência, o que significa inclusão social.

Segundo informações da Organização das Nações Unidas, ONU, cerca de 10\% da população dos países em desenvolvimento é formada de pessoas com algum tipo de deficiência.

Segundo o IBGE, no censo 2000, existiam no Brasil, por exemplo, naquele ano, 24,6 milhões de pessoas com algum tipo de deficiência ou incapacidade, que constituem, portanto, em um segmento da população carente de ações públicas que lhe permitam acessibilidade aos diferentes recursos como garantia de uma vida melhor.

Verifica-se, assim, a necessidade de se instituir programas, como, por exemplo, de eliminação das barreiras arquitetônicas, promovendo um conceito de "desenho universal", que garanta a acessibilidade às edificações, vias públicas, mobiliários urbanos, transportes e habitações que permitam a equiparação de oportunidades para todos.

A acessibilidade tem sofrido um grande investimento nas últimas décadas em várias áreas. Atualmente estão em andamento obras e serviços de adequação do espaço urbano e dos edifícios às necessidades de inclusão de toda população.

Também na área de informática, por exemplo, estão sendo desenvolvidos programas que fornecem meios de acessibilidade. Essas ferramentas permitem que pessoas com deficiência, nos seus mais variados segmentos, possam se utilizar dos recursos que a informática oferece. As ferramentas fornecidas pela informática são: leitores para deficientes visuais, teclados virtuais para pessoas com deficiência motora ou com dificuldades de coordenação motora, e sintetizadores de voz para pessoas com problemas de fala.

Assim, os países encontram-se em desenvolvimento para um melhor atendimento e oferta para as pessoas com deficiência. Sobre a inclusão, afirma Gugel (2006, p. 162): 
Os Países membros devem iniciar medidas que removam os obstáculos à participação no ambiente físico. Tais medidas devem desenvolver padrões e diretrizes e considerar a promulgação de leis para garantir a acessibilidade a várias áreas da sociedade, tais como moradia, edifícios, serviços de transportes públicos e outros meios de transporte, ruas e outros ambientes externos.

No Brasil foi criado pela Presidência da República o CONADE - Conselho Nacional dos Direitos das Pessoas Portadoras de Deficiência, que é um órgão superior de deliberação colegiada instituído para acompanhar e avaliar o desenvolvimento de uma política nacional para a inclusão da pessoa com deficiência e das políticas setoriais de educação, saúde, trabalho, assistência social, transporte, cultura, turismo, desporto, lazer e política urbana dirigidos a esse grupo social.

Estudando as novas tendências internacionais em turismo, verificamos a necessidade de investimentos estratégicos em ações de sustentabilidade e acessibilidade. Entender as necessidades dos turistas e viajantes com deficiência ou mobilidade reduzida, adaptar os equipamentos e espaços de acesso público de uso turístico de modo eficaz conforme normas de acessibilidade e assumir a igualdade de oportunidade como um direito universal passa a ser atitudes fundamentais para esse setor, como afirma Lorentz (2006, p. 208):

Todos têm direito de serem autores das normas que regem a vida societária. Este princípio moderno da igualdade serve para uma maior inclusão dos cidadãos nos procedimentos de justificação, de aplicação das normas jurídicas (...) com vistas à inclusão e à promoção social de um grupo que esteja em situação de desvantagem perante os demais.

O turismo acessível não deve ser entendido apenas como um direito social, mas como uma interessante oportunidade de mercado e de negócio para o setor. Enquanto essa atividade for restringida em nosso país teremos apenas a intenção de uma área importante para o desenvolvimento econômico, na verdade o turismo no Brasil ainda é uma esperança de crescimento social e econômico, mas que se encontra estagnado ou com pouquíssimo investimento governamental. Nesse sentido afirma o Ministério do Turismo, (2006, p. 17): 
O turismo tem impacto, negativo, pela sua falta de capacidade de inclusão social no Brasil (...). O turismo pode contribuir decisivamente para o desenvolvimento sustentável e para a inclusão social porque agrega um conjunto de dimensões favoráveis à solidariedade e à integração social.

Dois campos de atuação legislativa se desenvolvem, estabelecendo obrigações em favor do portador de deficiências (...). O Brasil aderiu e se obrigou e, outro, estritamente nacional, embora, visando ao cumprimento dessas normas internacionais, porém, adequando-se às peculiaridades do País. Ministério do Turismo, (2006, p. 17)

Ampliou-se, nos últimos anos, a discussão em torno do tema de inclusão das pessoas com deficiência na sociedade e o meio para atendê-las.

O significado de acessibilidade não é apenas o de permitir que pessoas com deficiência participem das atividades que incluam o uso de produtos, serviços e informação, mas também o de facilitar a inclusão e utilização destes por todas as parcelas de uma população. A inclusão social também depende dos meios fornecidos para que as pessoas que possuem certa limitação possam se fazer presentes e ativas em todos os tipos de atividade em geral. Resende (2004, p. 40) afirma que:

As conseqüências de vivenciar uma desestrutura organizada são sentidas, sobretudo pelas pessoas com deficiência, pois elas fazem parte do conjunto populacional brasileiro e também ocupam os espaços da cidade, só que, para terem dignidade em seus atos de vida diária, necessitam de infra estrutura adequada, o que, habitualmente, já é complicado para a maior parte da população que vive na cidade.

A Organização Mundial de Saúde, OMS, emitiu a Classificação Internacional de Deficiências, Atividades e Desvantagens (ICIDH) sobre os processos de incapacidade e fornece os vários meios existentes para diferenciar as dimensões e domínios que caracterizam a deficiência:

- Estado de Saúde quer dizer mudanças patológicas, algo anormal que acontece ao indivíduo, sintomas e sinais de doença; 
- Deficiências alguém reconhece a existência da situação os sinais são exteriorizados, a doença clínica é visível;

- Incapacidade são as limitações das atividades;

- Desvantagens quando os indivíduos estão em restrição da participação.

\subsection{O turismo e a questão da deficiência}

Os deficientes, como todos os turistas, possuem expectativas e necessidades em suas viagens. Essas podem ser comuns a todos ou mais específicas pelas condições de limitações em que alguns se encontram. A indústria turística começa a adotar uma estratégia de comercialização diferenciada, observando que a concepção de um produto turístico não deve obedecer a um padrão determinado de cliente, dado que cada indivíduo tem necessidades diferentes e específicas.

Existem algumas prioridades que são de consenso comum aos turistas. São elas: o respeito à dignidade no acesso aos serviços; serviços de informação especializados; informação precisa e integrada no que concerne aos serviços a dispensar; conhecimento das necessidades específicas de cada indivíduo no que toca aos serviços a oferecer; serviços de transportes e informação adequados; eliminação de barreiras; acesso a uma infra-estrutura turística; normalização de padrões de acessibilidade em todos os países.

As seguintes declarações e recomendações são importantes, pois foram expressas pelos participantes com deficiência no seminário internacional de Turismo para Todos "Deficiência e Liberdade de Movimentos", em Junho de 1999, em Roma:

- $\quad$ As pessoas com deficiência têm direitos iguais às demais pessoas quanto à plena participação na comunidade e, consequentemente, ao acesso a edifícios, às atividades de lazer, aos sistemas de transporte, à informação como ao direito de viajar. As associações de e para as pessoas com deficiência reivindicam que este direito seja reconhecido como um fato adquirido. 
- A primeira expectativa das pessoas com deficiência é a de serem reconhecidas como titulares de direitos iguais às demais pessoas e de que esse reconhecimento seja tácito. A deficiência não significa doença. Uma pessoa com deficiência não é diferente das outras.

- O nível de acessibilidade do meio físico influencia largamente as necessidades específicas das pessoas com deficiência: um meio ambiente acessível reduz consideravelmente os problemas com que se deparam e, portanto, as necessidades. O conhecimento do grau de acessibilidade dos pontos turísticos pode ajudar a respectiva indústria a determinar quais as atitudes a adotar em relação aos utentes com deficiência.

- $\quad$ Por último, as necessidades da pessoa com deficiência não são assim tão diferentes, mas as atitudes, relativamente ao grau de acessibilidade do meio físico têm de ser conhecidas.

- As pessoas com deficiência são as que melhor podem falar sobre as respectivas necessidades.

- $\quad$ As pessoas com deficiência são olhadas como grandes consumidores.

- $\quad$ As pessoas com deficiência têm o direito de corrigir e atualizar a informação.

- $\quad$ Alguns profissionais de turismo não estão interessados nos clientes com deficiência porque muitas vezes pensam que não são suficientemente ricos.

- $\quad$ Existem hotéis que têm relutância em receber pessoas com deficiência porque temem que possam incomodar os outros hospedes.

- Algumas companhias aéreas adotam normas que são muito discriminatórias para as pessoas com deficiência.

- A noção de acessibilidade é muito flexível e frequentemente interpretada de forma errônea.

- As pessoas que trabalham na área turística com a acessibilidade devem estar atentas para vários pontos, tais como:

- $\quad$ Pessoas com deficiência não são apenas as pessoas que utilizam a cadeira de rodas.

- Os alojamentos devem sofrer uma preparação prévia para essas pessoas com necessidades especiais. 
- $\quad$ As pessoas com deficiência devem fazer parte dos planos e medidas tomadas para ajudar na acessibilidade. Elas sabem as dificuldades que enfrentam no dia a dia

- $\quad$ As pessoas com deficiência devem ter direito à autonomia, isto é, de se conduzirem em vez de serem conduzidas. Assim como as necessidades e os desejos de cada indivíduo devem ser respeitados.

A exigência de qualidade e de conforto não são contraditórias com a acessibilidade, mas o contrário é verdadeiro. A criação de um bom produto implica no reconhecimento do mercado potencial que as pessoas com deficiência representam e isso conduz a um modelo que engloba as qualidades do turismo para todos, facilitando não só o acesso às atividades turísticas, mas promovendo uma oferta turística com qualidade, segurança, conforto e beleza.

Aprofundar o conhecimento das necessidades dos turistas com deficiência e, em âmbitos locais e nacionais, dispensar uma maior atenção a esta questão, contribuirá para que se consiga uma igualdade de oportunidades para estas pessoas a quem, muitas vezes, foi negada o direito ao lazer devido à falta de acessibilidade das instalações turísticas.

No próximo capítulo se discutirá a questão da acessibilidade do turismo, tomando como foco o caso de Formosa/GO, buscando-se relacionar a esta questão o conceito de desenvolvimento sustentável e a questão do poder público local e tendo por base a pesquisa realizada. 


\section{CAPÍTULO II - Um pouco da história local - algumas notas sobre o campo}

A cidade de Formosa, conforme a literatura de Chauvet (2005) tem a sua origem no século XVIII, fundada por aventureiros, que buscavam ouro das minas dos Guaiazes. Ali se encontram diversas grutas, como as da Fazenda Araras com inscrições que atestam a existência de índios, quando da chegada dos colonizadores. Um povoado cresceu logo abaixo do encontro do Rio Itiquira com o Rio Paranã, o arraial de Santo Antônio, povoado pelos crioulos que já criavam gado e viviam nessa região. Com o crescimento do povoado e da sua importância ele passou a ser conhecido por Arraial dos Couros, pois ali as moradias eram cobertas com peles de gado. O município guarda até hoje traços desse passado. Basta caminhar por suas ruas para perceber belas construções seculares como a Catedral de Nossa Senhora da Imaculada Conceição e o Colégio São José. Constata-se ao percorrer as ruas da cidade, que não houve por parte dos órgãos competentes, um trabalho de conscientização da população, visando à preservação do casario antigo e das fachadas das antigas construções coloniais. Vê-se, portanto, que vários casarões foram derrubados

dando lugar a edifícios modernos e que destoam da história e cultura da cidade de Formosa. É verdade que esse mesmo fenômeno também ocorreu em muitas cidades antigas do País.

Por volta de 1843, a vila teve seu nome mudado, passando a ser chamada Vila Formosa da Imperatriz, nome escolhido pela beleza do local e em homenagem à Imperatriz D. Teresa Cristina. Em 1877, foi guindada à categoria de cidade, com o nome de Formosa da Imperatriz, mais tarde, e até hoje, apenas Formosa.

Seus primeiros habitantes eram da própria região, os quais vieram em busca do ouro das minas dos Guaiazes, localizadas na fazenda Araras. Eram mineradores, vindos de São Paulo, para fazer a vida e buscar riquezas no sertão goiano. Sucessivamente vieram também baianos, mineiros, gaúchos e estrangeiros da Síria, do Japão, da Holanda, da França, da Itália, da Espanha. Hoje, além de seus descendentes, Formosa possui em sua população pessoas vindas de várias partes do Brasil e do mundo.

Com situação geográfica e climática privilegiada, Formosa está situada a $75 \mathrm{~km}$ de Brasília e $280 \mathrm{~km}$ de Goiânia, em uma altitude de $918 \mathrm{~m}$ e área de $7.200 \mathrm{~km}^{2}$, sendo a sua 
temperatura média de $25^{\circ} \mathrm{C}$ e a população de mais de 100 mil habitantes, conforme disposto no guia: Formosa: turismo, cultura, lazer e serviços, 2003.

As vias de acesso à cidade são a BR-020, conhecida como rodovia Brasília-Formosa, a rodovia GO-430, que faz a ligação com Planaltina de Goiás, sendo cortada por outra rodovia, a GO118, que liga o Distrito Federal à Chapada dos Veadeiros. Ainda pode ser considerada como acesso à GO-116, que liga Formosa ao Salto do Itiquira.

Pela sua posição geográfica e pelo seu desenvolvimento, Formosa é também conhecida como O Portal do Nordeste Goiano, sendo o pólo de captação e irradiação de toda a região. Tem o privilégio de ser o início de três grandes bacias - Bacia do Amazonas, representada pelo ribeirão Bandeirinha, Bacia do Prata, pelo ribeirão Pipiripau e São Francisco, pelo ribeirão Santa Rita.

O relevo é caracterizado por extensos chapadões, terras vermelhas, com lugares planos, baixos ou elevados. A vegetação é de cerrado com pequenos bosques e florestas.

As atividades econômicas mais importantes estão ligadas ao comércio, à agricultura, à pecuária, à avicultura e à indústria madeireira. A proximidade de Formosa com Brasília levou a sua inclusão na RIDE - Região Integrada de Desenvolvimento do Entorno do Distrito Federal, que é um plano governamental que busca criar condições de desenvolvimento sustentável das cidades que compõem a região do entorno. A cidade, além de fornecedora de produtos e mão-de-obra para o Distrito Federal, vem mostrando sua importância na prestação de serviços para a população do nordeste goiano.

O município conta atualmente com um dos maiores rebanhos de Goiás, com mais de 200 mil cabeças de gado. A produção de alimentos orgânicos é uma atividade de sustentabilidade, que vem crescendo em toda a região. Os pequenos produtores investem em frutos do cerrado para a confecção de doces, licores, sorvetes e picolés. Existe uma grande procura dos turistas pelo sabor diferenciado desses frutos. 
Formosa apresenta características que a distinguem em relação aos aspectos naturais. Possui vários pontos turísticos belíssimos, como o salto do Itiquira, a Lagoa Feia, o Buraco das Araras, o Buraco das Andorinhas, o Lajeado, as Cachoeiras do Nassin, a Cachoeira de São Pedro, o Sitio Arqueológico do JK, a Pedreira Toca da Onça e muitos outros que formam o roteiro turístico da cidade, que possui importantes atrativos turísticos, tendo elementos culturais marcantes. Tais características poderiam servir como incremento para o turismo local, um turismo para todos.

\subsection{Procedimentos metodológicos: as técnicas e o campo}

A pesquisa realizada tendo abordagem qualitativa compreendeu o trabalho de campo, com registro das informações em diário de campo e a realização de entrevistas. $\mathrm{O}$ roteiro das entrevistas foi definido como flexível, em razão da natureza do delineamento da pesquisa, isto é, o estudo diagnóstico com bases em conversas informais.

A técnica de pesquisa - entrevista - foi realizada com moradores, gestores e proprietários de estabelecimentos do trade turístico da cidade de Formosa/GO. Escolheu-se, em função do tema da pesquisa e da limitação temporal, os seguintes sujeitos para serem entrevistados, representando, desta forma, o universo amostral (entrevistas e roteiro anexos) - Tabela 01 na sequência.

\section{Tabela 01 - Entrevistados.}

\begin{tabular}{c|c|c|c|c|c}
$\begin{array}{c}\text { Número de } \\
\begin{array}{c}\text { Identificação da } \\
\text { Entrevista }\end{array}\end{array}$ & Entrevistado $^{2}$ & $\begin{array}{c}\text { Local de } \\
\text { realização da } \\
\text { entrevista }\end{array}$ & Ocupação & $\begin{array}{c}\text { Duração da } \\
\text { entrevista }\end{array}$ & $\begin{array}{c}\text { Data de } \\
\text { realização da } \\
\text { entrevista }\end{array}$ \\
\hline 01 & Marte & $\begin{array}{c}\text { Loja de sua } \\
\text { propriedade } \\
\text { Formosa/GO }\end{array}$ & Empresário & 35 minutos & $03 / 03 / 2009$ \\
\hline 02 & Roberto & $\begin{array}{c}\text { Faculdade Iesgo } \\
\text { Formosa/GO }\end{array}$ & Professor & 32 minutos & $05 / 03 / 2009$
\end{tabular}

${ }^{2}$ Os nomes utilizados na tabela são fictícios para preservar a identidade dos entrevistados. 


\begin{tabular}{|c|c|c|c|c|c|}
\hline 03 & Helena & $\begin{array}{l}\text { Faculdade } \\
\text { Cambury } \\
\text { Formosa/GO }\end{array}$ & Moradora & 20 minutos & $10 / 03 / 2009$ \\
\hline 04 & Catarina & $\begin{array}{l}\text { Comércio de } \\
\text { Formosa } \\
\text { Formosa/GO }\end{array}$ & Administradora & 26 minutos & $11 / 03 / 2009$ \\
\hline 05 & Raimunda & $\begin{array}{l}\text { Secretária de } \\
\text { Turismo } \\
\text { Formosa/GO }\end{array}$ & Gestor público & 40 minutos & $27 / 03 / 2009$ \\
\hline 06 & Márcia & $\begin{array}{c}\text { Secretária de } \\
\text { Turismo } \\
\text { Formosa/GO }\end{array}$ & Gestor público & 1hora & $27 / 03 / 2009$ \\
\hline 07 & Pereira & $\begin{array}{c}\text { Hotel da cidade } \\
\text { Formosa/GO }\end{array}$ & Funcionário & 25 minutos & $30 / 03 / 2009$ \\
\hline 08 & José & $\begin{array}{l}\text { Hotel da cidade } \\
\text { Formosa/GO }\end{array}$ & Proprietário & 50minutos & $30 / 03 / 2009$ \\
\hline 09 & João & $\begin{array}{l}\text { Bar da cidade } \\
\text { Formosa/GO }\end{array}$ & Proprietário & 30 minutos & $05 / 04 / 2009$ \\
\hline 10 & Manoel & $\begin{array}{c}\text { Restaurante da } \\
\text { cidade } \\
\text { Formosa/GO }\end{array}$ & Proprietário & 35 minutos & $05 / 04 / 2009$ \\
\hline 11 & Marga & $\begin{array}{c}\text { Faculdade } \\
\text { Cambury } \\
\text { Formosa/GO }\end{array}$ & $\begin{array}{l}\text { Estudante } \\
\text { (deficiente) }\end{array}$ & 1 hora & $22 / 04 / 2009$ \\
\hline
\end{tabular}

Fonte: Borges, Ana Beatriz, com base em trabalho de campo, Formosa/GO, 2009.

Desta forma, pode-se observar que as entrevistas tiveram duração aproximada de 30 minutos. Além disso, também foram consultados documentos relativos à história da cidade e obtidas, junto a órgãos municipais, fotografias que indicam os principais pontos turísticos locais. Estes registros fotográficos foram utilizados no presente trabalho com a respectiva fonte. Ainda assim, foram retiradas fotos por parte da pesquisadora, contudo não expressam a qualidade das que estão dispostas neste trabalho e por esta razão optou-se por utilizar as de outras fontes. 


\section{CAPÍTULO III - Formosa: o turismo como estratégia para o desenvolvimento sustentável local e a acessibilidade}

O desenvolvimento do turismo na cidade de Formosa pode contemplar aspectos relacionados ao patrimônio natural e ao patrimônio material e imaterial local.

Conforme definido pelo Instituto do Patrimônio Histórico e Artístico Nacional, Iphan (2007, p. 20) patrimônio cultural:

é o conjunto de bens culturais que determinada comunidade, reconhece como valor histórico, artístico, arquitetônico, arqueológico ou ambiental, e que, portanto, entende que deva ser preservado para as gerações futuras (...). As formas de preservação desses bens são distintas: para os bens de natureza material como igrejas, casas, palácios, obras de arte e acervos documentais, utiliza-se o tombamento. Para os de natureza imaterial, como celebrações, danças, lugares e formas de expressão, utiliza-se o Registro. Ambos os instrumentos são implementados pelo Poder Público em nível municipal, estadual e federal.

De acordo com o Plano Diretor da cidade, "a cidade apresenta importante patrimônio natural a ser preservado e incorporado de maneira sustentável pela exploração turística, como o parque municipal Mata da Bica, a Lagoa Feia, o Salto do Itiquira, a Toca da Onça, a Cachoeira do Bandeirinha, o Buraco das Araras, a Gruta das Andorinhas, a Cachoeira do Bisnau, entre outros. Por outro lado, a cidade também possui um patrimônio histórico-cultural considerável, visto ser uma cidade cuja origem se deu no ciclo do ouro, durante o século XVIII, como anteriormente visto" (2003, p.45). Com relação ao patrimônio histórico cultural, há duas iniciativas do governo local: a exposição permanente de artesanato nas salas do CAT - Centro de Atendimento ao Turista, e o Museu Couros, com a sistematização histórica da formação do município. Também no setor central da cidade estão espalhados diversos casarões em estilo colonial. 


\section{A constituição do conjunto turístico de Formosa/GO: atrativos naturais}

No estado de Goiás, destacam-se a Reserva da Biosfera do Cerrado e o Parque Nacional da Chapada dos Veadeiros, Sítio Natural do Patrimônio Mundial concedido pela Unesco. O município de Formosa, por seu turno, apresenta alto potencial de desenvolvimento de ecoturismo, uma categoria turística que vem crescendo nos últimos anos no país, caracterizada pela integração sustentável com o meio ambiente. As atrações de Formosa são predominantemente de caráter ecológico. Porém existem algumas atrações turísticas de natureza histórica, como por exemplo, o Museu Couros, onde são encontradas informações sobre a fundação, ocupação e desenvolvimento histórico do município.

\section{a) Patrimônio natural e o turismo em Formosa}

No que concerne às atrações naturais, a mais conhecida e divulgada é o Salto do Itiquira. Nas proximidades do Salto, é possível visitar também mais outras tantas cachoeiras, cascatas e nascentes de água mineral. No caminho para o Itiquira, estão a Toca da Onça e a cachoeira do Bandeirinha, bastante freqüentadas pelos moradores de Formosa. Destacam-se, também, a rampa de vôo livre e a pista de Motocross. Além destas, o roteiro ecoturístico pode vir a contemplar: a Lagoa Feia, o Buraco das Araras, a Gruta das Andorinhas, entre outros pontos que a seguir estão descritos. 


\section{Figura 01: Salto do Itiquira}

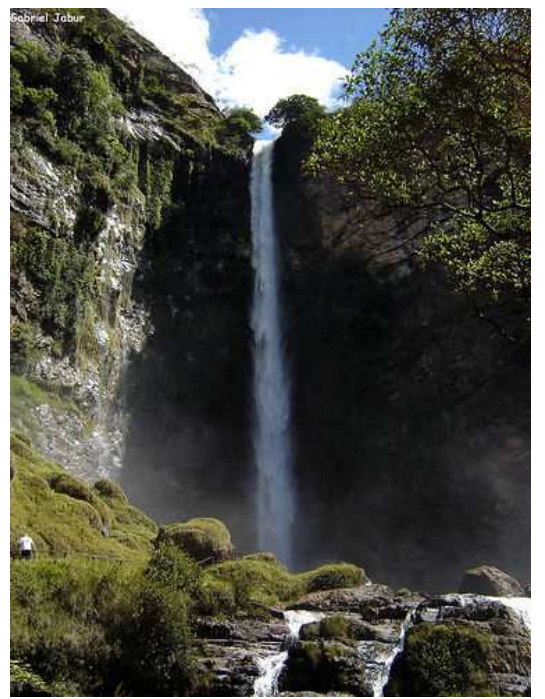

Fonte: Jabur, Gabriel, s/d.

O Salto do Itiquira, localizado no Vale do Paranã, situa-se a $34 \mathrm{~km}$ do centro de Formosa. Sua cachoeira possui uma queda d'água de 168 metros de altura, considerada a mais alta da América Latina. Formado pelo rio Itiquira, o Salto e o curso d'água que segue todo o parque de preservação ambiental é de água cristalina. $\mathrm{Na}$ área fora do Salto, existem clubes com piscinas de água corrente, trilhas ecológicas, sauna, camping, chalés e restaurantes. O parque é administrado por uma concessionária até o ano de 2009.

A concepção do Complexo Turístico Itiquira é de oferecer as pessoas de todas as idades, lazer, descanso e o desenvolvimento pessoal e espiritual. Com uma natureza tão exuberante, o complexo entende que possui uma responsabilidade ecológica, no cuidado e na preservação do meio ambiente. Não obstante, carece de infra-estrutura adequada para o recebimento de turistas com deficiência.

A Lagoa Feia é a maior lagoa do centro-oeste e dista $5 \mathrm{~km}$ do centro da cidade, com estrada asfaltada. Suas águas tem origem na Mata da Bica. À sua direita, encontra-se uma reserva ecológica com 24.500 alqueires de mata, pertencentes ao Exercito Brasileiro, onde se pode observar 
espécies raras da fauna e flora. A lagoa é bastante concorrida para prática de esportes aquáticos, como o jet ski, pescaria e competições de canoagem, além de passeios de lancha.

Como se verifica por meio dos registros fotográficos abaixo, também nesse ponto turístico, não se nota a acessibilidade como elemento integrante da concepção de turismo adotada pelos empreendimentos locais.

\section{Figura 02: Lagoa Feia}

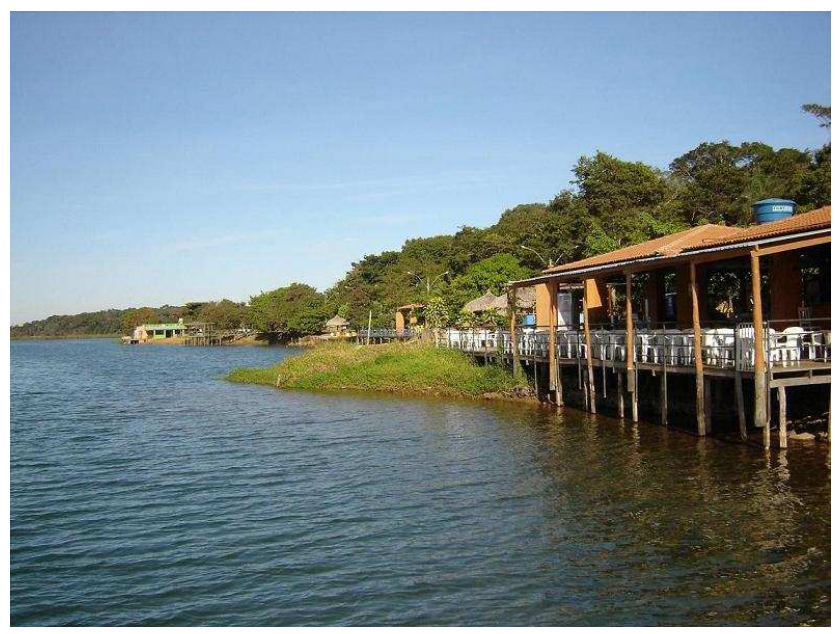

Fonte: http://img119.imageshack.us/img119/8543/f30de2.jpg

Como se pode notar pela fotografia acima, a Lagoa Feia é aberta ao público, havendo em suas margens várias instalações poluentes. Além disso, efluentes gerados na área urbana são lançados na lagoa sem tratamento, situação que pode causar danos irreversíveis ao meio ambiente.

Além disso, os projetos existentes no plano diretor prevêem o remanejamento das 52 famílias mais atingidas pelos alagamentos, a locação e pavimentação de um sistema viário definitivo, a construção do conjunto habitacional Nova Formosa com 280 casas, e a recuperação 
ambiental, remodelação e reurbanização das margens da Lagoa Feia ${ }^{3}$, prevendo remoção e reconstrução dos restaurantes panorâmicos, implantação de ciclovia e outros equipamentos e infraestrutura de lazer.

Em parecer deliberativo do Conselho Municipal do Meio Ambiente, datado de 11/04/2003, foi registrada a necessidade de reavaliação do projeto apresentado, uma vez que as margens da lagoa seriam ocupadas, devendo ao contrário, serem reflorestadas, de acordo com aquele parecer. Outros fatos colaboraram na rejeição do projeto: estacionamento entre mata ciliar e o lago, permanência de bares e restaurantes na orla, construção de praia e não de nascente existente no local.

Assim, a acessibilidade e os projetos de melhoria da Lagoa Feia permanecem estagnados. O que leva à degradação das áreas reformadas, à falta de limpeza e de cuidado com um ponto turístico de grande importância para a cidade de Formosa.

Outro ponto turístico importante é o Buraco das Araras - figura 3, abaixo indicada -, é constituído por uma enorme depressão, possui cerca de 150 metros de largura por 120 metros de profundidade. A vegetação do interior é completamente diferente da circundante, com árvores centenárias, rochas com características vulcânicas e poços de água transparente, além de várias espécies de pássaros como a arara-vermelha e animais selvagens. Dizem que o buraco foi criado pela queda de um meteoro. Verdade ou não, é um lugar misterioso e fascinante para os seus visitantes.

\footnotetext{
${ }^{3}$ Não foram fornecidos pela Prefeitura Municipal de Formosa maiores detalhes concernentes ao projeto da lagoa Feia, tampouco acesso às plantas e edital de licitação já em andamento (Notas de campo, 2008).
} 
Figura 03: Buraco das Araras

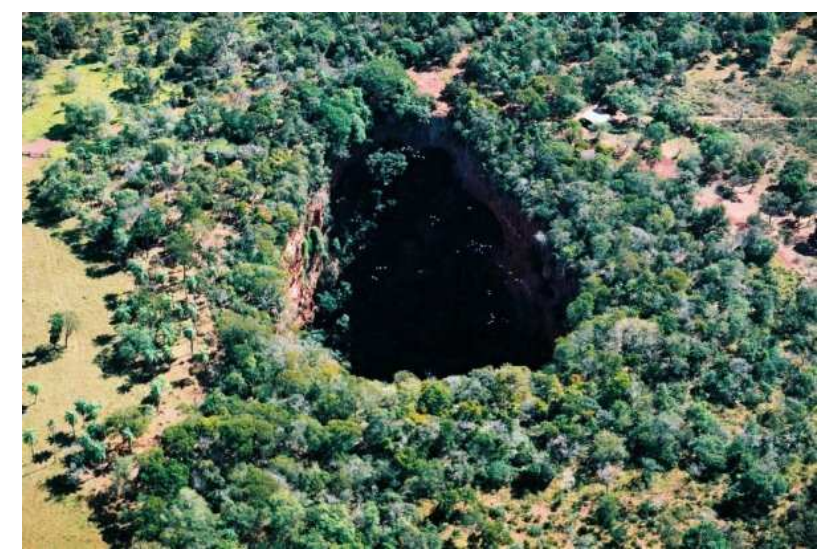

Fonte: Associação de Reservas, Parques e Patrimônio Nacional, s/d. (http://www.repams.org.br/rppns.php?cod=38)

A Gruta das Andorinhas é um complexo de grutas e buracos. Possui 250 metros de profundidade e em seu interior existe um rio de águas frescas e cristalinas. A gruta ainda não foi mapeada. Encontra-se a $32 \mathrm{Km}$ do centro da cidade e próximo está o Rio Lajeado.

\section{Figura 04: A Gruta das Andorinhas}

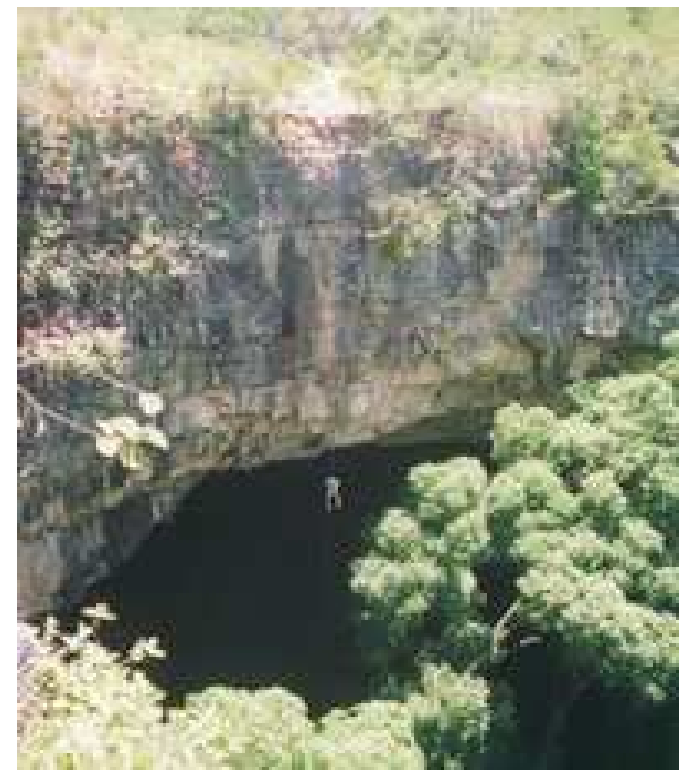

Fonte : SETUR - Secretária de Turismo Brasília, s/d. 
A Pedreira Toca da Onça é uma serie de grutas na base de um paredão de pedra que brota do solo, com 50 metros de altura. Nas grutas são encontradas inscrições rupestres e várias estalactites, algumas a céu aberto. Compondo o lugar, existe um córrego próximo à Toca. O Rio Bandeirinha - rio que abastece o município e está a 918 metros de altitude - está localizado a $3 \mathrm{~km}$ do centro da cidade, oferece um verdadeiro espetáculo de cachoeiras e piscinas naturais. Outro atrativo é o Lajeado, constituído de $500 \mathrm{~m}^{2}$ de rochas lisas e contínuas no leito do ribeirão, com 5 metros de desnível, formando cascatas que terminam num poço de 2 metros de profundidade de água, que contorna a Serra da Capetinga, formando dezenas de piscinas naturais, incrustadas nas rochas. O Lajeado está a $38 \mathrm{~km}$ do centro de Formosa. A Cachoeira da Capetinga localiza-se a 43 km do centro de Formosa. São 100 metros de cachoeiras, num desnível total de 130 metros, com 6 pequenas quedas d'água, ao longo do percurso, com 2 poços naturais para banho, além de uma linda vista, com um mirante natural. Por fim, o Sitio Arqueológico está localizado no Bisnau próximo a BR-020 entre o povoado de Bezerra e JK, conta com diversas inscrições rupestres que podem ser visitadas pelos turistas.

Digno de registro - com base no trabalho de observação realizado nos locais apontados -, é que em muitos dos casos, a precariedade da infra-estrutura neles existente para o acolhimento dos turistas, especialmente dos turistas com deficiência é fatídica.

\section{b) Patrimônio imaterial e material e o turismo em Formosa}

Ainda no âmbito do turismo cultural, a cidade possui diversas festas religiosas, que poderiam contemplar o conjunto turístico, tendo em vista sua importância local e se tratar de um patrimônio cultural/imaterial do povo. A mais tradicional delas é a festa do Divino Espírito Santo realizada no mês de maio, com a caminhada dos devotos pelas ruas da cidade empunhando bandeiras do Divino Espírito Santo e pedindo donativos para a Igreja Católica, que os reverte em ações de caridade (cf. Notas de campo, 2008). Além desta, outras são celebradas ao longo do ano, 
como: Folia de Reis no mês de Dezembro, Nossa Senhora da Abadia mês de agosto e Nossa Senhora da Conceição no mês de novembro.

\section{Patrimônio imaterial}

Considerado patrimônio imaterial as festas religiosas consistem em importante momento de celebração e apresentam como significado o resgate da cultura popular local. A Festa do Divino Espírito Santo está entre as maiores do gênero no Brasil e é a que mais reúne pessoas em todo o Centro-Oeste brasileiro, a seguir apresentada Figura 5.

\section{Figura 05: Festa do Divino Espírito Santo}

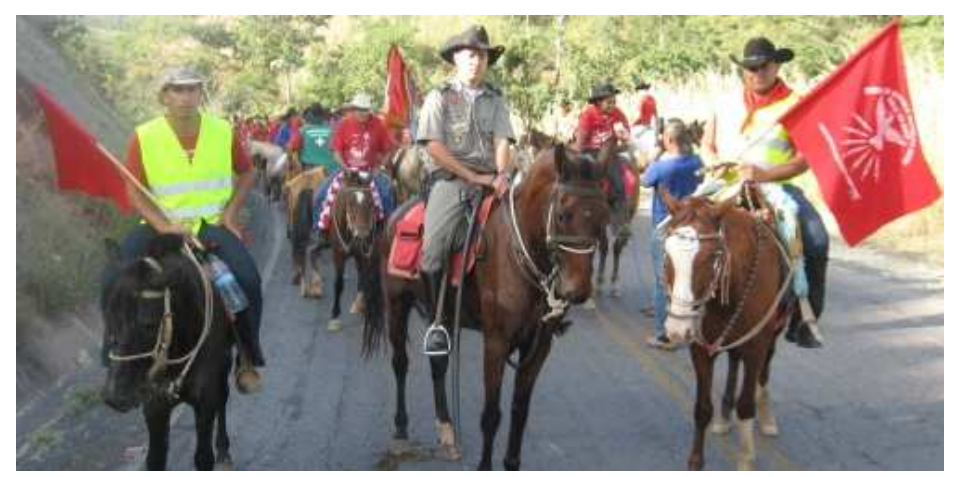

Fonte: Batalhão da Polícia Militar de Formosa/GO, P5 16 BPM, s/d.

Como se percebe da Fotografia, as pessoas se reúnem e no último dia da programação, desde a madruga acontece uma caminhada pelas ruas da cidade, com os devotos empunhando bandeiras do Divino Espírito Santo e pedindo donativos para a Igreja Católica, que reverte em ações de caridade. 


\section{Patrimônio material}

O patrimônio material de Formosa é representado pelo artesanato local, Museu dos Couros, igrejas e casarões. O artesanato local é constituído com base em trabalhos com cabaças, pedras, pinturas, bordados, licores e doces produzidos com frutas nativas do cerrado, como gabiroba, articum, gravatá, cagaita e pequi.

O Museu dos Couros é uma instituição que busca resgatar e manter a história e as tradições do município. Para tanto, o Museu apresenta duas exposições, que já fazem parte do calendário de eventos da cidade, que são: a semana da moagem e a semana da farinha. Durante a semana da moagem se instala uma feira, cujo objetivo é estimular o conhecimento por parte da população dos subprodutos de um engenho de cana-de-açúcar, como a rapadura, o melado, a moçabranca, a cachaça e o puxa-puxa. Neste momento ocorre a visitação de escolares e de parte da população local. A semana da farinha constitui o segundo evento promovido pelo museu, nela o objetivo é resgatar o antigo ritual da fabricação das farinhas de mandioca e do polvilho, demonstrando ainda a arte tradicional da tecelagem.

Como em todas as cidades que sofreram processo de colonização europeu durante o século XVIII, um dos mais importantes pontos turísticos de Formosa é sua Catedral.

Figura 06: Catedral de Nossa Senhora da Imaculada Conceição

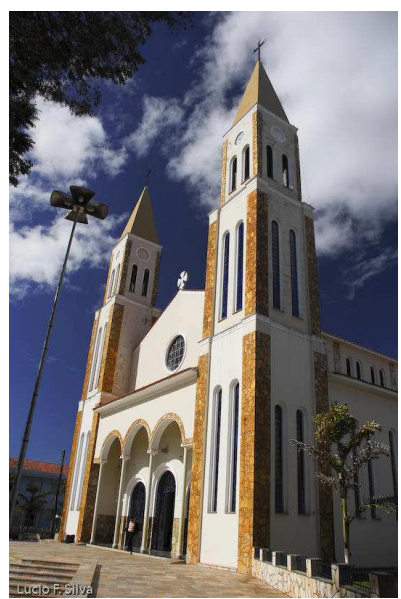

Fonte: Amorin, Elder Alves de, s/d. 
Sua construção data de 1800 , a igreja possui nave única e duas torres com relógios. O altar principal possui uma imagem de Maria ao centro, com imagens de anjos ao redor e Jesus na cruz, logo abaixo.

Os casarões - remanescentes do século XVIII - também são pontos turísticos marcantes da cidade, como se nota a seguir:

Figura 07: Casarão Antigo da Cidade de Formosa

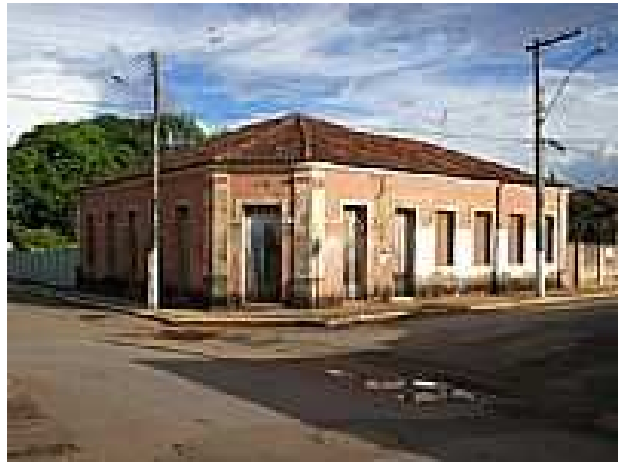

Fonte: Amorim, Elder Alves de, s/d.

A Secretaria de Turismo e Cultura do município informou que alguns casarões já estão definidos como parte do Patrimônio Cultural da Cidade de Formosa, tais como:

- Bairro Centro, Praça Rui Barbosa, uma casa de fundos na qual foram mantidas suas características originais em relação às técnicas de construção da época, inclusive a do telhado. Para sua preservação e manutenção, suas paredes foram pintadas com PVA látex, as portas e janelas com tinta a óleo. Assim, fica fácil a limpeza e a conservação da loja comercial que é a utilidade do local na atualidade. Nesta mesma praça existem outras casas tombadas, que também possuem o mesmo modo de conservação e que mantém características originais e técnicas de construção da época.

- Praça São Vicente no bairro Pau Ferro. Casa localizada na Avenida Anhanguera, 180 que 
mantém todas as suas características originais, dentre as quais a pintura das portas, das janelas, o piso e o telhado. Outros casarões também compõem o patrimônio cultural dessa praça, com suas fachadas preservadas.

Existem ainda outros bairros com casarões tombados, tais como Formosinha e Centro. É interessante registrar que alguns casarões funcionam como estabelecimentos comerciais, como o Hotel Imperatriz e o Restaurante Casarão.

Como se pôde observar, com base na descrição e nas fotografias destacadas, existe na cidade de Formosa uma gama de atrativos naturais, bem como urbanos, que podem funcionar como indicadores da necessidade de estabelecimento de um conjunto turístico, isto é, pontos indicativos para a visitação de turistas, mas também para a visitação e melhor apropriação das pessoas que vivem na própria cidade.

\section{Infra-estrutura local: a viabilidade do turismo em Formosa/GO}

Em relação à infra-estrutura local para a inserção de um roteiro turístico na cidade de Formosa/GO, os aspectos a serem destacados são: (a) as vias e as formas de acesso à cidade, isto é, as vias de acesso que se dirigem ao local, bem como, a forma como será realizada, se por via aérea ou terrestre e, no caso do primeiro tipo, identificar o local de onde os turistas partem para terem como destino a cidade de Formosa; (b) a infra-estrutura local para receber o turista - que diz respeito à hospitalidade - e a verificação da acessibilidade internamente, tanto para os moradores locais, quanto para os turistas/visitantes.

A cidade de Formosa possui nos seus perímetros urbano e rural um número total de 57 estabelecimentos comerciais destinados à alimentação e à hospedagem, sendo que destes 12 são hotéis, 6 são campings e 9 são restaurantes (cf. informações obtidas in lócus, CAT, 2008). Há também hotéis-fazenda e alguns restaurantes de comida caseira típica do município ou pescados, que se localizam fora da região central da cidade, estando localizados na zona rural. Todos os hotéis do município são considerados de categoria simples. Dos 12 hotéis relacionados, $50 \%$ estão situados 
na área urbana e os 50\% restantes estão localizados próximos às atrações naturais na área rural. Os campings, ao contrário, estão todos localizados nas margens das estradas que dão acesso a estas atrações, havendo uma grande concentração nos arredores do Salto do Itiquira, enquanto os restaurantes estão na sua grande maioria concentrados na área urbana, com exceção de três deles, localizados no caminho do Itiquira, e outros dois, nas margens da lagoa Feia, especializados em pescados.

De acordo com dados obtidos junto à Prefeitura Municipal, a maior freqüência de visitantes se dá entre os meses de julho a dezembro, que coincide com o período de calendário de eventos da cidade. A maior festa popular de Formosa acontece em julho, a exposição agropecuária (Expoagro), tradicionalmente realizada há 50 anos. Leilões, grandes shows artísticos e eleições das rainhas da Exposição e do Rodeio lotam o Parque de Exposições. O aniversário da cidade é comemorado no primeiro dia de agosto e, embora com festividade própria, quase sempre coincide com a programação da Expoagro.

\section{A questão da acessibilidade}

Até então se verificou que a cidade de Formosa apresenta alguns pontos turísticos importantes, tanto no que diz respeito aos aspectos ambientais (ecoturismo) quanto aqueles relacionados ao patrimônio material e imaterial da cidade - o que foi caracterizado como conjunto turístico -, conforme a compreensão de patrimônio cultural (IPHAN, 2008). Também foi realizada uma rápida apresentação da infra-estrutura turística da cidade. Todavia, cabe ressaltar a questão da relação entre infra-estrutura e acessibilidade. Neste âmbito foram utilizados, além dos dados obtidos por meio da observação direta, registros das entrevistas realizadas, conforme tabela 01 apresentada anteriormente.

Falar de acessibilidade em termos gerais é garantir a possibilidade do acesso, da aproximação, da utilização e do manuseio dos equipamentos e dos ambientes da sociedade por todos. 
Conforme a ABNT NBR 9050:2004 a acessibilidade é a condição de alcance, percepção e entendimento para a utilização com segurança e autonomia de edificações, espaço, mobiliário, equipamento urbano e elementos. Segundo a Lei Federal 10.098/00, a definição de acessibilidade é a possibilidade e condição de alcance para a utilização, com segurança e autonomia, de espaços, mobiliários e equipamentos urbanos, das edificações, dos transportes e dos sistemas e meios de comunicação, por pessoas portadoras de deficiência ou com mobilidade reduzida.

Durante o trabalho de campo, o conjunto turístico indicado foi objeto de visita, buscando detectar, prioritariamente, os obstáculos arquitetônicos ou naturais à visitação dos pontos indicados. Os restaurantes, bares e o comércio em geral, por exemplo, não possuem acesso adequado para as pessoas com deficiência: faltam rampas, as calçadas apresentam níveis diferentes e os degraus por toda a cidade dificultam a vida também dos idosos, de pais com carrinhos de bebês, dos obesos, dos que empurram carrinhos de compras, dos trabalhadores no serviço de carga e descarga e de todos que, em determinado momento, se vêem na condição de pedestres. Observou-se ainda a indisponibilidade de cardápios e informações turísticas em Braille ou em outros formatos a permitir a acessibilidade dos deficientes visuais.

Constatou-se, no entanto, que, em praticamente todos os referidos pontos turísticos $80 \%$ dos pontos visitados - são necessários cuidados especiais para sua preservação e o aprimoramento da sua infra-estrutura, hoje muito precária, para o atendimento da população local e o acolhimento/hospitalidade de turistas.

Conforme um dos entrevistados (Entrevista 08), cujo perfil é caracterizado por ser representante dos bares e restaurantes de Formosa, o investimento no turismo acessível seria um incentivo para o crescimento de vários setores, não obstante permitir maior acesso à população local - particularmente das pessoas com problemas de locomoção - aos espaços ou pontos turísticos da cidade (conjunto turístico). Desta forma, ao passo que o turismo pode resultar em novos empreendimentos e consequentemente na melhoria da qualidade dos serviços prestados, tendo, por seu turno, um incremento econômico local (sustentabilidade econômica); traz, de maneira indireta, a possibilidade de assegurar um retorno econômico para o comércio e para o setor produtivo de modo 
geral, contribuindo, por exemplo, com a oferta de trabalho/emprego e a maior geração de renda em nível local.

O turismo pode contribuir decisivamente para o desenvolvimento sustentável e para a inclusão social porque agrega um conjunto de dimensões favoráveis à solidariedade e à integração social. Em primeiro lugar pela sua própria natureza, o turismo opera pela ruptura do isolamento, provocando o contato entre diferentes culturas e ocasionando interações de múltiplos e variados atores. Com isso, propicia o conhecimento e a valorização de determinados ambientes e comunidades, estimulando o respeito e o interesse pela sua preservação. Em segundo lugar, as interações se dão em clima de reduzida tensão, favorecendo o entendimento entre os autores. Terceiro, o turismo exibe forte potencial de criação e ampliação de oportunidades de trabalho e geração de renda. Por tudo isso, e por envolver uma ampla multiplicidade de segmentos, o turismo contribui para o reconhecimento e valorização da diversidade e para o estabelecimento entre grupos sociais. (MINISTÉRIO DO TURISMO, 2006, p.22)

Não obstante a obrigatoriedade e importância da referida adaptação, é necessário compreender que o cumprimento das leis e normas da acessibilidade vai muito mais além que, por exemplo, o simples oferecimento de rampas de acesso ou da eliminação de barreiras arquitetônicas.

Complementa as informações registradas com base na observação direta (visitação do conjunto turístico), a realização de entrevistas, cuja finalidade foi avaliar em que medida os cidadãos de Formosa - detentores de diferentes perfis - compreendem a acessibilidade naquela cidade, do ponto de vista das barreiras arquitetônicas e naturais. O primeiro aspecto destacado foi à infraestrutura local, isto é, no atendimento ao turista, na eliminação de barreiras arquitetônicas, na disponibilização de ajudas técnicas, na oferta de intérpretes da língua de sinais, entre outras. Em relação a este elemento, todos os informantes registraram que a cidade não possui infra-estrutura para o desenvolvimento do turismo local e nem é acessível à sua própria população. Assim, a conclusão é que nenhum dos pontos identificados como conjunto turístico de Formosa está devidamente adaptado em termos de infra-estrutura para dispensar o tratamento com a qualidade que 
os turistas de modo geral merecem, e, particularmente, aqueles com deficiência como, por exemplo, na questão do acesso.

Um dos entrevistados, cujo perfil corresponde a uma pessoa deficiente de mobilidade, destacou em sua fala as dificuldades de locomoção na cidade de Formosa, como segue: "para que respeitem o direito de ir e vir das pessoas com deficiência é preciso que proporcionem aos mesmos uma melhor condição de vida principalmente no lazer e no turismo" (Entrevista 11).

Deste modo, pelo trecho da entrevista apresentado observa-se que as falas dos entrevistados sem dificuldade de locomoção é reforçada pela da pessoa com tal dificuldade, o que demonstra uma "consciência" crítica do cidadão em Formosa/GO em relação à questão da mobilidade. Isto indica haver uma legitimação por parte do grupo entrevistado no estabelecimento da acessibilidade como demanda social, tanto para buscar uma perspectiva sustentável do turismo, quanto para possibilitar que os cidadãos da cidade possam se locomover com maior facilidade, meio às dificuldades impostas pelas barreiras arquitetônicas locais. Houve uniformidade também em relação à omissão do próprio governo no cumprimento das normas de acessibilidade que lhe dizem respeito, como, por exemplo, a necessária adaptação das calçadas, posto que 100\% dos entrevistados, que correspondem ao universo de informantes desta pesquisa - ressaltam tal omissão.

Conforme a pesquisa realizada, fica clara a necessidade de investimento em infraestrutura. Todos concordam que esse investimento, em conjunto com a observância das normas da acessibilidade, será de grande valia para o desenvolvimento e para o incremento do turismo na região.

Este mesmo percentual, também ratifica a dificuldade financeira para a condução dos negócios naquela cidade, indicando em suas falas a necessidade de realização de obras de infraestrutura que possibilitem a acessibilidade, bem como o turismo e o desenvolvimento do comércio, como se registra na seqüência: "para a adaptação dos banheiros e espaços no interior dos estabelecimentos, para a contratação de pessoas qualificadas, inclusive com deficiência, e para um planejamento geral para o efetivo cumprimento das normas de acessibilidade” Entrevistado 01. 
Todos os entrevistados concordam que um investimento conjunto dos órgãos competentes, sociedade e empresas, na acessibilidade de Formosa, seria um investimento favorável para o incremento da região, não apenas do turismo, mas de todas as atividades em geral. O transporte teria uma grande melhora, como as vias de acesso, as praças, os pontos turísticos, o que seria um ganho para toda a comunidade local e, claro, para os tão esperados turistas.

Em síntese, todos possuíam o mesmo ponto de vista sobre a falta de acessibilidade nos equipamentos turísticos da região. Falaram sobre a importância da acessibilidade, apontando-a como um fator de incremento do turismo e indicando como solução um maior investimento público e dos próprios empreendimentos particulares nesta questão. Os aspectos destacados pelos entrevistados podem constituir como parâmetro para um estudo de viabilidade do turismo em Formosa, o que também é trazido pela literatura, pois o turismo possui uma grande capacidade de promoção da participação de todos. As possibilidades de contribuição do desenvolvimento turístico à geração de inclusão social estão vinculadas às suas características. O que se torna importante, pois, conforme Andréa Santini (2006, p.23) o século XX, especialmente a partir da segunda metade, foi marcado por um desenvolvimento técnico - cientifico com proporções nunca antes vistas. Paradoxalmente, o modelo econômico global garantiu apenas a uma minoria o usufruto destas conquistas, tendo aprofundado as desigualdades econômicas e sociais, além de causar danos significativos ao meio ambiente. Inicia-se o novo milênio com sérios desafios que exigem o repensar e o recriar do nosso modelo civilizatório. $\mathrm{Na}$ área do turismo volta-se o pensamento para a acessibilidade e para a formação de um novo paradigma, que traz a consciência de que o que diz respeito a um individuo, também diz respeito a todos - somos um só corpo integrado e intrinsecamente interdependentes.

O turismo empodera o território. Quem quiser usufruí-lo, terá de visitá-lo, vivenciálo e consumi-lo. Por tanto sua infra-estrutura deve atender ao público visitante. Possui a capacidade de transformar o meio ambiente e a cultura em ativos estratégicos de desenvolvimento. O turismo possui a dependência dos atores locais de outros setores econômicos, que lhes aumenta a sua capacidade de participar nos processos decisórios locais. As possibilidades de emprego de mão de obra local como fator de agregação de valor turístico. O estimulo ao empreendedorismo, a 
acessibilidade local induzido pela demanda turística no destino receptivo. A participação de organizações das comunidades locais na conservação dos espaços localizados no entorno dos atrativos e dos espaços de visitação turística. (MINISTERIO DO TURISMO, 2006, p.42)

Por fim, os entrevistados afirmaram que a implantação da acessibilidade geraria não só empregos como também uma maior atratividade turística para a região. Como o entrevistado 6 observou, a qualidade de vida de toda a comunidade é reflexo do investimento e do cuidado com a cidade, por parte do setor público e do privado. O acesso a todos é uma forma de melhorar a qualidade de vida dos moradores de Formosa. 


\section{CONSIDERAÇÕES FINAIS}

O objetivo geral desta pesquisa foi o de compreender o cenário do turismo na cidade de Formosa/GO, em especial analisando a acessibilidade do local. Neste âmbito, buscou-se identificar o perfil do turista de Formosa, que é um turista de negócio e em menor proporção os de aventura e verificar a necessidade de implantar uma política de desenvolvimento sustentável com especial ênfase na acessibilidade, que pode vir a se tornar um fator importante de incremento da atividade turística da região.

Com base nos dados coletados - a partir de registros em diário de campo, fotografia e de entrevistas realizadas - pode-se afirmar que os moradores, comerciantes e gestores públicos da cidade de Formosa apontaram as existentes limitações à acessibilidade em especial em pontos turísticos e indicaram-na como possível fonte de incremento para o turismo local.

Todavia, é importante enfatizar - conforme discutido com base na literatura estudada que o investimento no turismo com acessibilidade, com qualidade de infra-estrutura para todos, incluindo as pessoas com deficiência, incrementaria e inovaria o crescimento da atividade turística, o que é de fundamental importância para o desenvolvimento da região, permitindo que haja uma valorização desses atrativos pelas populações vizinhas, inclusive do grande cliente potencial que é Brasília. O turismo acessível seria um diferencial, podendo vir a contribuir na construção de uma proposta de sustentabilidade (desenvolvimento sustentável) local.

Contudo o turismo necessita ser desenvolvido de forma planejada e consciente para que possa se tornar uma atividade sustentável e não predatória, respeitando a diversidade e necessidades de todos os cidadãos que possuem potencial para serem turistas, entre eles as pessoas com deficiência e ou com mobilidade reduzida.

Mundialmente, o Brasil é reconhecido como um dos paises que possui a legislação mais completa para garantir os direitos das pessoas com deficiência, mas na prática do cotidiano desse segmento ainda há entraves para que estes estejam participando ativamente do processo de desenvolvimento do país. 
Essa é uma preocupação não só dos brasileiros, é uma preocupação em âmbito internacional, e com isto a Organização dos Estados Americanos estabeleceu o período de 2006/2016 como a Década das Pessoas com Deficiência com o tema: Pelos Direitos e Dignidade das Pessoas com Deficiência.

Como exemplo de outros países, em Portugal à cidade de Lousã acolheu o I Congresso Nacional de Turismo Acessível. O presidente da Autarquia, em conjunto com a Provedoria Municipal das Pessoas com Incapacidade da Lousã, começou a pensar em desenvolver um plano estratégico de soluções integradas de acessibilidade para todos.

Da teoria à prática, em dois anos o Município conseguiu redefinir espaços, acessos públicos e sensibilizar os privados para a importância de locais acessíveis a todas as pessoas, muitos deles, já possuem informação em braille.

Foi apresentado um roteiro turístico básico, com os pontos turísticos principais da cidade de Formosa/GO e a sua atual condição de equipamento de acessibilidade e possibilidades futuras de implantação de tais meios.

Contudo, conforme observado pelos registros de campo e com base nas entrevistas realizadas, há pouco investimento no turismo na região de Formosa. Este tipo de constatação acaba por expressar na fala dos entrevistados a necessidade de viabilização de uma infra-estrutura adequada para os seus visitantes, visto que não há.

Outro aspecto relevante que pode ser destacado com base nas falas e nos registros de diário de campo, é o fato de que não houve - por parte do poder público local - a preservação dos seus atrativos turísticos naturais, resultando no reduzido desenvolvimento turístico da região, o que - para os entrevistados - tem prejudicado o crescimento local e dificultado o aumento de emprego e o desenvolvimento da cidade.

Falar do conceito de acessibilidade turística em Formosa chega, portanto, a ser quase irreal, pois a cidade, governo e comunidade, além de não estarem cumprido com a legislação 
pertinente sobre a matéria, nem ainda não se deram conta do quanto assegurar o direito às pessoas com deficiência ao lazer e turismo contribuiria para potencializar o crescimento turístico e, consequentemente, desenvolvimento econômico e social da região.

Com base nos registros do trabalho de campo, constatou-se também que os bares, restaurantes e hotéis não se encontram preparados para o atendimento da demanda turística e, na maioria dos casos, nem sequer tem a noção ou iniciativa do investimento na acessibilidade. Se em sua concepção e execução as políticas públicas locais e iniciativas privadas levassem em conta o turismo com sustentabilidade e acessibilidade, isto certamente se constituiria em um atrativo a mais para a divulgação da região e o fortalecimento da sua atividade turística. Os brasilienses estão sempre à procura de lugares diferentes e de uma proposta de turismo interessante, por que não Formosa?

O pressuposto apresentado de que a acessibilidade poderá ser o diferencial para o sucesso da atividade turística em Formosa tende a ser confirmado, ainda que de forma preliminar tendo em vista que este trabalho constitui um diagnóstico sobre a situação estudada e não pretende ser conclusivo. Todavia, acredita-se que - conforme os autores discutidos e as recomendações da Organização Mundial de Turismo - a acessibilidade deve ser vista como uma estratégia para o desenvolvimento sustentável local, buscando-se com o incremento do turismo a valorização das riquezas da região, da comunidade local e de ações voltadas para garantir o acesso para todos. Para que os visitantes, inclusive pessoas com deficiência, também possam aproveitar dessas riquezas, com respeito ao meio ambiente e preservando a cultura local.

Por fim, considera-se - com base nos dados coletados durante a pesquisa, bem como em contribuições de autores sobre o tema - que o turismo pode ser trabalhado com um diferencial, investindo na acessibilidade, com planos de ação junto à comunidade e com a preservação da identidade cultural da região, criando assim, um incremento em todas as atividades relacionadas ao turismo, tornando Formosa uma cidade muito mais formosa e para todos e viabilizando pelos menos três critérios do desenvolvimento sustentável: os fatores econômico, social e o cultural (Sachs, 2000). 


\section{REFERÊNCIAS BIBLIOGRÁFICAS}

ACERENZA, Miguel Ágel. Administração do Turismo: Conceitos e organização. Bauru, SP: EDUSC, 2002. p. 62.

BARRETTO, Margarita. Turismo, Cultura e Sociedade. Caxias do Sul, RS: Educs, 2006.

CASTELLI, Geraldo. Turismo: atividade marcante. Caxias do Sul: EDUCS, 2001. p. 148.

CHAUVET, Gustavo. Brasília e Formosa: 4500 anos de História. Goiânia: Kelps, 2005.

CORNER, Dolores Martins Rodriguez. Introdução ao turismo - direção e redação Amparo. São Paulo: Roca, 2001. p. 63.

FUSTER, Luiz Fernandez. Teoría y técnica Del turismo. Madri: Nacional, 1973.

GUGEL, Maria aparecida. Pessoas com deficiência. Goiânia: UCG, 2006.

KALUME, Pedro de Alcântara. Deficientes. São Paulo: LTDA, 2006. p. 13.

LEMOS, Amalia Ines Geraiges. Turismo: impactos socioambientais. São Paulo: Hucitec, 2001.

LORENTZ, Lutiana Nacur. A norma da Igualdade e o trabalho das Pessoas Portadoras de deficiência. São Paulo: 2006.

MAMEDE, Gladstom. Direito do turismo: Legislação Específica Aplicada. São Paulo: Atlas, 2004.

PAGE, Stephen. Transporte e Turismo. Porto Alegre: Bookman, 2001.

RESENDE. Ana Paula Crosara. Todos na cidade: $O$ direito a acessibilidade das pessoas com deficiência física em Uberlândia. Uberlândia: EDUFU, 2004. p. 40.

SACHS, Ignacy. Caminhos para o desenvolvimento sustentável. Rio de Janeiro: Garamond, 2000. 
SANTINI, Andréia. Acessibilidade: você também tem compromisso. Brasília: CONADE, 2006.

SASSAKI, Romeu Kazumi. Inclusão no Lazer e Turismo: Em Busca da Qualidade de Vida. São Paulo: Áurea, 2003.

. Vida Independente: história, movimento, liderança, conceito, filosofia e fundamentos. São Paulo: RNR, 2003.

SWARBROOKE, Jonh. Turismo Sustentável: Meio ambiente e economia. São Paulo: Aleph, 2000.

XIMENES, Sérgio, 1954 - Dicionário da língua portuguesa. - 3 ed. ver. e ampl. São Paulo: Ediouro, 2001.

\section{OUTROS DOCUMENTOS CONSULTADOS}

A Procissão do Divino em Formosa. In: Alcance. Formosa: ano VI, n 49.

$<\underline{\text { http://www.brasilparatodos.com.br/> }}$. Acesso em 02/04/2009.

<http://www.vereadoramaragabrilli.com.br/destaque/138-por-uma-cidade-mais-acessivel-evisitada.html >. Acesso em 23/04/2009.

BRASIL (1998). Decreto $\mathrm{n}^{\circ} 2.521$ de 20 de março de 1998 - Regulamento do Serviço de Transporte Rodoviário Interestadual e Internacional de Passageiros. Art. 3 inciso V.

FORMOSA. Projeto Preservação Patrimônios Culturais. Formosa: Prefeitura Municipal de Goiás: 2006.

GOIÁS, Secretária do Planejamento e Desenvolvimento. Plano diretor do município de formosa/GO: relatório final consolidado. Outubro: 2003. 
GOIÁS. Formosa: turismo, cultura, lazer e serviços. Os melhores roteiros e serviços. Goiânia: Alquimia Publicidade, 2003.

MINISTÉRIO DO TURISMO. Turismo Social: Diálogos do Turismo, Uma Viagem de Inclusão. Rio de Janeiro: IBAM, 2006. p. 17.

ORGANIZAÇÃO MUNDIAL DO TURISMO, Introdução ao Turismo. Redação e Direção Amparo Sancho. São Paulo: Roca, 2001.

PLANO PILOTO 50 ANOS. Cartilha de preservação. Brasília: IPHAN, 2007.

SASSAKI, Romeu Kazumi. Como chamar as pessoas que têm deficiência? São Paulo, janeiro de 2005. Disponível em : <http://www.movimentovida.hpg.com.br/romeu1.htm>. Acessado em 19/04/2009.

\section{FOTOS PONTOS TURÍSTICOS FORMOSA}

RPRN. "Buraco das Araras". Disponível em: www.repams.org.br/rppns.php?cod=38. Acessado em: 02/04/2009.

RPRN. “Lagoa Feia”. Disponível em: http://img119.imageshack.us/img119/8543/f30de2.jpg. Acessado em 02.04.2009. 


\begin{abstract}
ANEXOS
Perguntas para as entrevistas realizadas com moradores, gestores e comerciantes da cidade de Formosa:
\end{abstract}

1. O que você acha da acessibilidade na cidade de Formosa?

2. Os pontos turísticos, os hotéis, os restaurantes e os bares estão preparados para receber pessoas com deficiências físicas permanentes ou temporárias, idosos com dificuldade de locomoção ou mesmo carrinhos de bebê entre outras condições que dificultam o acesso?

3. Em sua opinião, quais são as medidas mais urgentes para tornar Formosa uma cidade com acessibilidade para todos?

4. Você acha que o incremento na área turística de Formosa poderia ser um gerador de emprego e desenvolvimento para a cidade?

5. Se a cidade de Formosa investisse na acessibilidade ocorreria um aumento no setor turístico? De imediato, quais seriam os principais pontos turísticos para este investimento? 
Lista dos hotéis, camping e restaurantes da cidade de Formosa

\begin{tabular}{|c|c|c|c|c|}
\hline $\begin{array}{l}\text { Número de } \\
\text { Identificação }\end{array}$ & Estabelecimentos & Tipo & Categoria & Localização \\
\hline 01 & ABC Palace & Hotel & Simples & Centro \\
\hline 02 & Serrador & Hotel & Simples & Centro \\
\hline 03 & Araras de Formosa & Hotel & Simples & $\begin{array}{l}\text { Distrito } \\
\text { Bezerra }\end{array}$ \\
\hline 04 & Advans II Chalés & Hotel & Simples & Lagoa Feia \\
\hline 05 & Bettos & Hotel & Simples & Centro \\
\hline 06 & Divisão & Hotel & Simples & $\begin{array}{c}\text { BR- } 020 \\
\text { Km } 15\end{array}$ \\
\hline 07 & Planalto & Hotel & Simples & Saída sul \\
\hline 08 & Pousada do Bosque & Hotel & Simples & Centro \\
\hline 09 & Itiquira & Hotel & Simples & Salto Itiquira \\
\hline 10 & Recanto Pedra Grande & Hotel & Simples & $\begin{array}{c}\text { Distrito Santa } \\
\text { Rosa } \\
\end{array}$ \\
\hline 11 & Arapuca & Camping & & $\begin{array}{c}\text { Itiquira } \mathrm{Km} \\
25 \\
\end{array}$ \\
\hline 12 & Dona Divina & Camping & & $\begin{array}{c}\text { Itiquira } \mathrm{Km} \\
26 \\
\end{array}$ \\
\hline 13 & Tião Borda & Camping & & $\begin{array}{c}\text { Itiquira } \mathrm{Km} \\
30 \\
\end{array}$ \\
\hline 14 & Itiquira & Camping & & Salto Itiquira \\
\hline 15 & Beira Rio & Camping & & $\begin{array}{l}\text { Parque } \\
\text { Itiquira } \\
\end{array}$ \\
\hline 16 & $\begin{array}{c}\text { Camping Clube do } \\
\text { Brasil } \\
\end{array}$ & Camping & & $\begin{array}{c}\text { Planaltina } \\
\text { Km } 22\end{array}$ \\
\hline 17 & João & Restaurante & A La carte & Lagoa Feia \\
\hline 18 & Portuguesa & Restaurante & Self service & Lagoa Feia \\
\hline 19 & San Francisco & Restaurante & Self service & Centro \\
\hline 20 & Casarão & Restaurante & Bufê & Centro \\
\hline 21 & Paladar & Restaurante & Bufê & Centro \\
\hline 22 & Churrascaria La Palma & Restaurante & Bufê & Centro \\
\hline 23 & Don Fernando & Restaurante & Rural bufê & Itiquira $\mathrm{Km} 7$ \\
\hline 24 & Beira Rio & Restaurante & Bufê & $\begin{array}{l}\text { Parque } \\
\text { Itiquira }\end{array}$ \\
\hline 25 & Itiquira & Restaurante & Bufê & Salto Itiquira \\
\hline 26 & Ponto Verde & Restaurante & $\begin{array}{c}\text { Bufe e self } \\
\text { service }\end{array}$ & Centro \\
\hline 27 & Fogão de Lenha & Restaurante & À la carte & Centro \\
\hline 28 & Pau Ferro & Pizzaria & & Centro \\
\hline 29 & Il Brasílico & Pizzaria & & Centro \\
\hline 30 & Gera & Pizzaria & & Centro \\
\hline
\end{tabular}

Fonte: Borges, Ana Beatriz, com base em trabalho de campo, Formosa/GO, 2009. 